
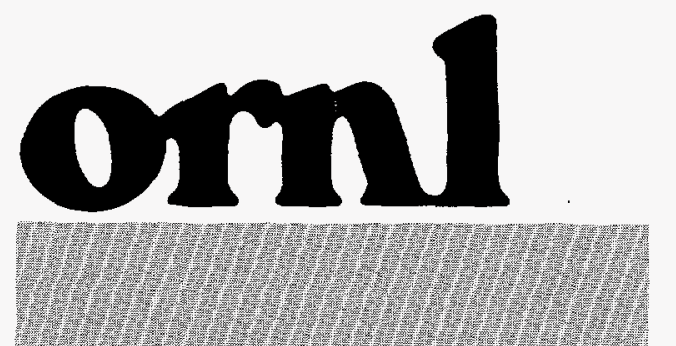

OAK RIDGE

NATIONAL

LABORATORY

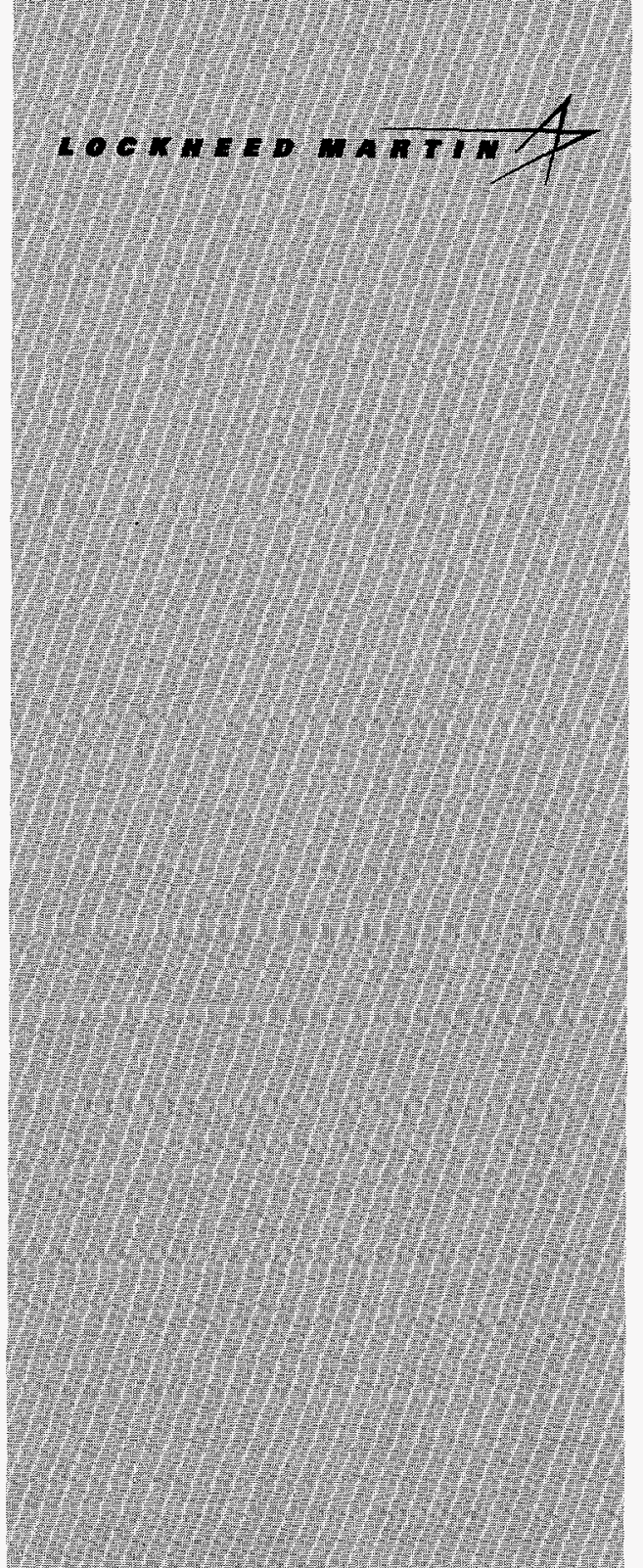

NANAGED ANO OPERATED BY LOEKHEED MARTN ENERGY RESEARCH CORPORATION FOA THE UNTEDOSTATES

DEPARTIENT OF ENEREY
RECEIVED

ORNL/TM-13502

NOV 261997

OSTI

DESCRIPTION OF THE CANADIAN PARTICULATE-FILL WASTE-PACKAGE (WP) SYSTEM FOR SPENT-NUCLEAR FUEL (SNF) AND ITS APPLICABILITY TO LIGHT-WATER

REACTOR SNF WPS WITH DEPLETED URANIUM-DIOXIDE FILL

\section{MASTEK

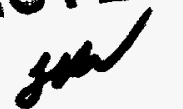

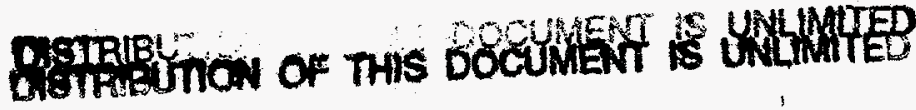

Prepared by

OAK RIDGE NATIONAL LABORATORY

Oak Ridge, Tennessee 37831

managed by

LOCKHEED MARTIN ENERGY RESEARCH CORP.

for the

U. S. DEPARTMENT OF ENERGY

under Contract No. DE-AC05-96OR22464 
This report has been reproduced directly from the best available copy.

Available to DOE and DOE contractors from the Office of Scientific and Technical Information, P. O. Box 62, Oak Ridge, TN 37831; prices available from (423) 576-8401, FTS 626-8401.

Available to the public from the National Technical Information Service, U.S. Department of Commerce, 5285 Port Royal Road, Springfield, VA 22161.

This report was prepared as an account of work sponsored by an agency of the United States Government. Neither the United States Government nor any agency thereof, nor any of their employees, makes any warranty, express or implied, or assumes any legal liability or responsibility for the accuracy, completeness, or usefulness of any information, apparatus, product, or process disclosed, or represents that its use would not infringe privately owned rights. Reference herein to any specific commercial product, process, or service by trade name, trademark, manufacturer, or otherwise, does not necessarily constitute or imply its endorsement, recommendation, or favoring by the United States Government or any agency thereof. The views and opinions of authors expressed herein do not necessarily state or reflect those of the United States Government of any agency thereof. 


\section{DISCLAIMER}

Portions of this document may be illegible electronic image products. Images are produced from the best available original document. 
Chemical Technology Division

\title{
DESCRIPTION OF THE CANADIAN PARTICULATE-FILL WASTE-PACKAGE (WP) SYSTEM FOR SPENT-NUCLEAR FUEL(SNF) AND ITS APPLICABILITY TO LIGHT-WATER REACTOR SNF WPS WITH DEPLETED URANIUM-DIOXIDE FILL
}

\author{
Charles W. Forsberg \\ Oak Ridge National Laboratory ${ }^{*}$ \\ P.O. Box 2008 \\ Oak Ridge, Tennessee 37831-6180 \\ Tel: (423) 574-6783 \\ Fax: (423) 574-9512 \\ Email: forsbergcw@ornl.gov
}

October 20, 1997

*Managed by Lockheed Martin Energy Research Corp. under contract DE-AC05-96OR22464 for the U.S. Department of Energy. 
3 


\section{CONTENTS}

LIST OF FIGURES $\ldots \ldots \ldots \ldots \ldots \ldots \ldots \ldots \ldots \ldots \ldots \ldots \ldots \ldots \ldots \ldots \ldots \ldots \ldots \ldots \ldots$

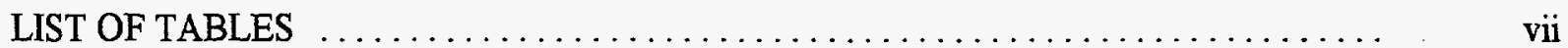

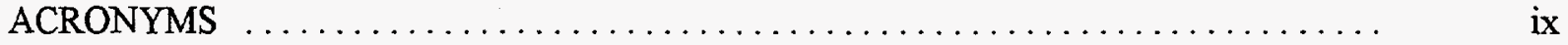

ACKNOWLEDGEMENT $\ldots \ldots \ldots \ldots \ldots \ldots \ldots \ldots \ldots \ldots \ldots \ldots \ldots \ldots \ldots \ldots \ldots \ldots \ldots$

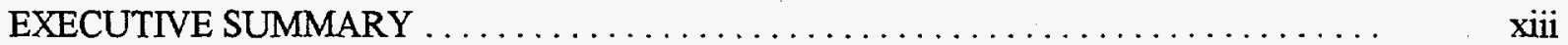

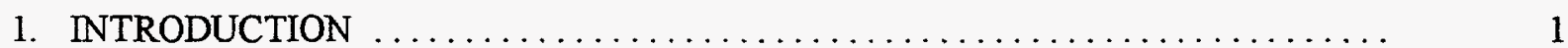

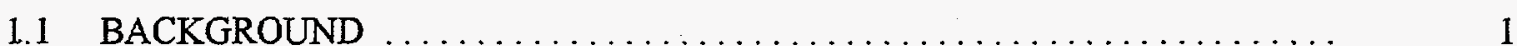

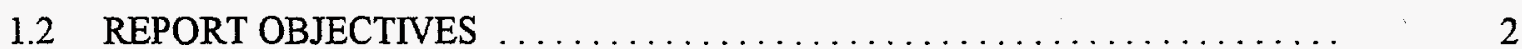

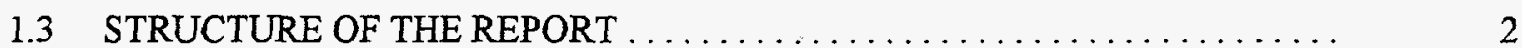

2. THE CANADIAN GEOLOGICAL REPOSITORY SYSTEM FOR DISPOSAL OF

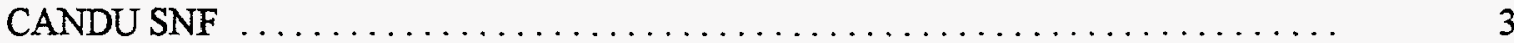

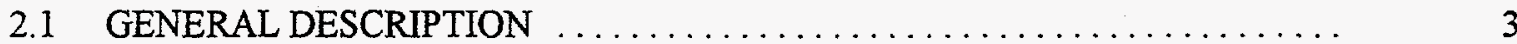

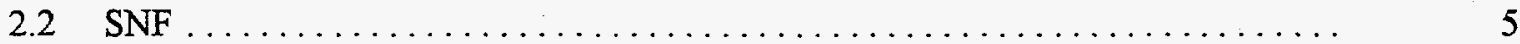

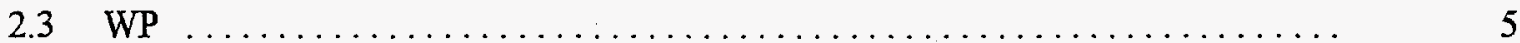

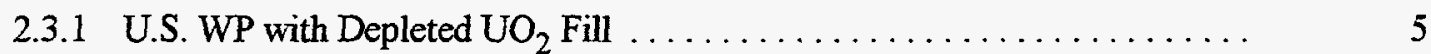

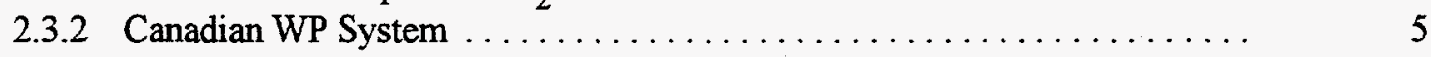

3. CANADIAN WP DEVELOPMENT PROGRAM $\ldots \ldots \ldots \ldots \ldots \ldots \ldots \ldots \ldots \ldots \ldots$

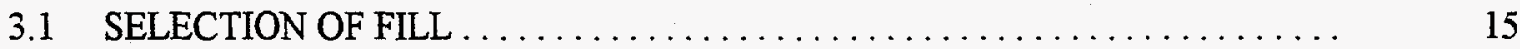

3.2 FULL-SCALE WP TESTS FOR REPOSITORY CONDITIONS . . . . . . . . . . . 21

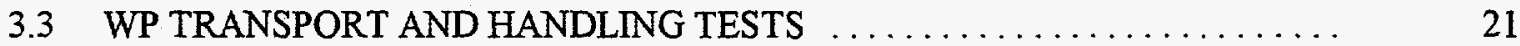

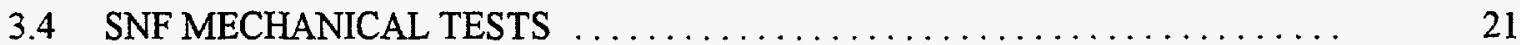

3.5 RECOVERY FROM WP MANUFACTURING FAILURE $\ldots \ldots \ldots \ldots \ldots \ldots \ldots$

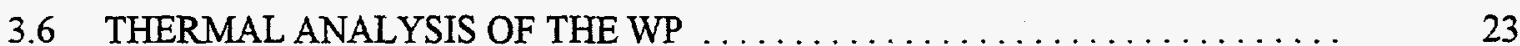

3.7 PRODUCTION FACILITIES FOR FILLING WPS $\ldots \ldots \ldots \ldots \ldots \ldots \ldots \ldots \ldots \ldots \ldots$

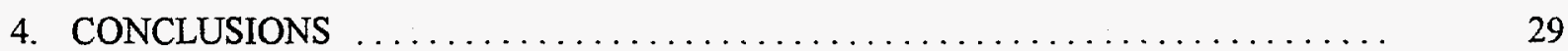

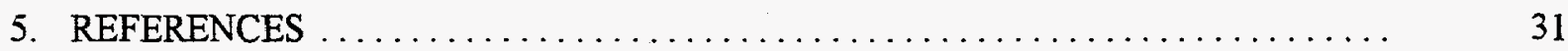

APPENDIX A: DESCRIPTION OF THE USE OF DEPLETED URANIUM DIOXIDE FILL $\mathbb{N}$ LWR SNF WPs $\ldots \ldots \ldots \ldots \ldots \ldots \ldots \ldots \ldots \ldots \ldots \ldots \ldots \ldots$ A-1

APPENDIX B: $\quad$ PUBLICATIONS ON THE USE OF DU FILL IN SNF WPS $\ldots \ldots \ldots \ldots$ 


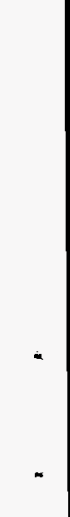




\section{LIST OF FIGURES}

Fig. ES.1 Open prototype Canadian WP with fill material $\ldots \ldots \ldots \ldots \ldots \ldots \ldots \ldots \ldots$

Fig. ES.2 Full-scale prorotypic WP $\ldots \ldots \ldots \ldots \ldots \ldots \ldots \ldots \ldots \ldots \ldots \ldots \ldots \ldots \ldots \ldots$

Fig. ES.3 Whiteshell Hydrostatic Test Facility to test WPs up to $10 \mathrm{MPa}$ and $150^{\circ} \mathrm{C} \ldots \ldots$ xvii

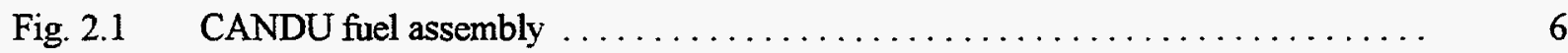

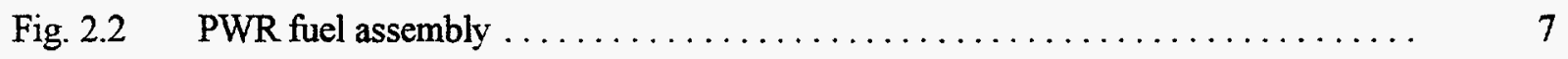

Fig. 2.3 Cross sections of CANDU and PWR fuel assemblies $\ldots \ldots \ldots \ldots \ldots \ldots \ldots . . \ldots$

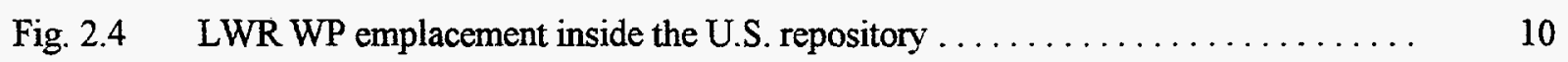

Fig. 2.5 One Canadian concept for CANDU SNF WPs and for disposal of WPs in grantie . 12

Fig. 3.1 Two-nuclear-fuel assembly particulate fill test on the Ontario Hydro large seismic

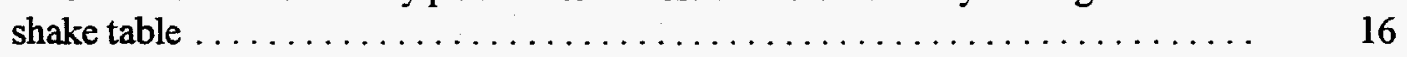

Fig. 3.2 Gravity filling of CANDU fuel assemblies followed by vibratory compacting ... . 17

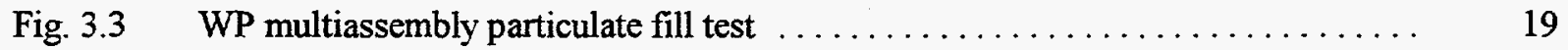

Fig. 3.4 Whiteshell Hydrostatic Test Facility to test WP at $10 \mathrm{MPa}$ and $150^{\circ} \mathrm{C} \ldots \ldots \ldots 22$

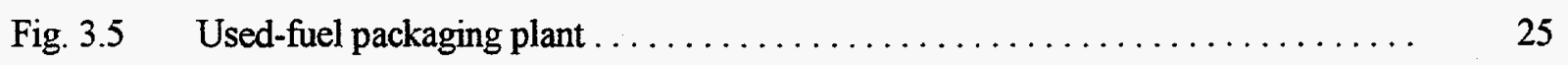

Fig. 3.6 Container filler and vibratory compactor $\ldots \ldots \ldots \ldots \ldots \ldots \ldots \ldots \ldots \ldots \ldots \ldots$

Fig. A.1 WP system and example loading sequence for DU particulates $\ldots \ldots \ldots \ldots$ A-4

Fig. A.2 Specific volume of selected uranium minerals vs evolution over time in oxidizing

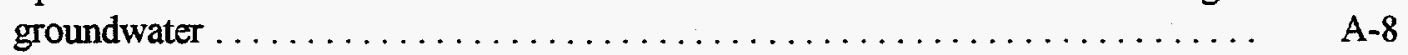

Fig. A.3 Conversion of $\mathrm{UO}_{2}$ to $\mathrm{U}_{3} \mathrm{O}_{8}$ with reduction in WP water and air permeability ... A A-9

Fig. A.4 Natural and man-made formation of uranium ore bodies $\ldots \ldots \ldots \ldots \ldots \ldots \ldots$ A-11 



\section{LIST OF TABLES}

Table 2.1 Conceptual designs of the Canadian and U.S. geological repository systems ..... 4

Table 2.2 Characteristics of CANDU and PWR SNF $\ldots \ldots \ldots \ldots \ldots \ldots \ldots \ldots \ldots$

Table 2.3 Conceptual Canadian and U.S. WP designs that use fill materials $\ldots \ldots \ldots \ldots \ldots$

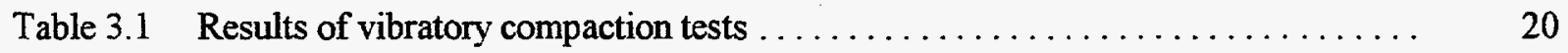

Table 3.2 One conceptual design of CANDU SNF used-fuel packaging plant $\ldots \ldots \ldots \ldots .24$

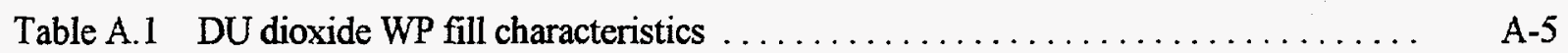





\section{ACRONYMS}

ASME American Society of Mechanical Engineers

AECL Atomic Energy of Canada Limited

BWR Boiling-water reactor

CANDU Canadian deuterium uranium

DOE U.S. Department of Energy

DU Depleted uranium

LWR Light-water reactor

MPC Multi-purpose canister

MTIHM Metric tons initial heavy metal

NRC U. S. Nuclear Regulatory Commission

NWTRB Nuclear Waste Technical Review Board

PWR Pressurized-water reactor

SNF Spent nuclear fuel

UFPP Used-Fuel Packaging Plant

WP Waste package 



\section{ACKNOWLEDGEMENT}

I would like to thank Atomic Energy of Canada Limited for providing technical information and photographs. Specific appreciation is given to Jane Sargent and J. Les Crosthwaite of Whiteshell

Laboratories, Pinawa, Manitoba, Canada, for assisting the author in understanding the Canadian Nuclear Fuel Waste Management Program. 



\section{EXECUTIVE SUMMARY}

The United States is beginning work on an advanced, light-water reactor (LWR), spent nuclear fuel (SNF), waste package (WP) that uses depleted uranium dioxide $\left(\mathrm{UO}_{2}\right)$ fill. The Canadian nuclear fuel waste management program has completed a 15-year development program of its repository concept for CANadian Deuterium Uranium (CANDU) reactor SNF. As one option, Canada has developed a WP that uses a glassbead or silica-sand fill. The Canadian development work on fill materials inside WPs can provide a guide for the development of LWR SNF WPs using depleted uranium (DU) fill materials. This report summarizes the Canadian work, identifies similarities and differences between the Canadian design and the design being investigated in the U.S. to use DU fill, and identifies what information is applicable to the development of a DU fill for LWR SNF WPs.

In both concepts, empty WPs are loaded with SNF, the void space between the fuel pins and the outer void space between SNF assemblies and the inner WP wall would be filled with small particles, the WPs are then sealed, and the WPs are placed into the repository.

CANDU and LWR SNF assemblies have different geometries, but both assemblies consist of $\mathrm{UO}_{2}$ pellets in zircalloy tubes. Both types of assemblies see similar environments in the reactor. However, the internal clearances within a CANDU assembly are smaller than those in a typical LWR assembly; thus, the Canadians must take added care when filling their assemblies with fill. The WP designs differ also because the proposed Canadian repository will be built in granite below the water table, whereas the proposed U.S. repository will be in tuff above the water table. The Canadian repository may be larger than the U.S. repository or repositories. The CANDU SNF produces less energy per ton of SNF than LWR SNF. In one design studied for the Canadian program, the repository would have a design capacity of 191,000 metric tons initial heavy metal (MTIHM) of SNF. The total quantities of U.S. LWR SNF are estimated at 87,900 MTIHM.

The proposed fill material for the U.S. LWR SNF WP is depleted $\mathrm{UO}_{2}$. The fill improves WP performance by providing (1) shielding, (2) reduced potential for repository nuclear criticality events, and (3) reduced long-term release of radionuclides from the WP in the repository. The DU fill lessens the longterm release of fission products and actinides from the WP into the environment by suppressing SNF dissolution by multiple mechanisms.

The Canadian program has developed a WP that uses high-silica, low-sodium, glass-bead or silica-sand fill to provide structural support to the WP against external hydrostatic pressures at repository depths. The particulate totally fills all voids inside the WP. The WP is a long-lived, thin-wall, titanium WP. At depths 
within the proposed Canadian repository, long-term hydrostatic pressure from groundwater may equal $10 \mathrm{MPa}(\sim 100 \mathrm{~atm})$ on the exterior of the WP. The fill prevents WP wall failure, WP collapse, and subsequent collapse of external-to-the-WP radionuclide barriers (bentonite clay) in the repository.

Canada initiated a large-scale, 15-year development and demonstration program to develop their repository concept. This included WP development. The Canadian tests demonstrated filling WPs containing simulated CANDU SNF with small particulates (Fig. ES.1). The investigations evaluated alternative fill materials, different particle sizes, different mixtures of particle sizes, vibratory filling at different vibrational frequencies and amplitudes, and other factors. Both small- and large-scale experiments indicate that the maximum practical packing density is about $70 \%$; that is, in a well-packed container, the solid particulate volume is about $70 \mathrm{vol} \%$ of the initial void, and $30 \mathrm{vol} \%$ of the initial void remains as voids between the fill particles. Vibratory filling was identified as the preferred option for this type of WP. It provided higher fill densities and shorter fill times. The Canadians also developed WP inspection and welding technologies (Fig. ES.2).

Larger-scale tests included successful, full-scale WP hydrostatic tests (at $10 \mathrm{MPa}$ and $150^{\circ} \mathrm{C}$ ) of the filled WP to confirm that all voids within the WP had been filled (Fig. ES.3) and that adequate support was provided by the particulates to the container wall. The particle-filled WP successfully passed multiple handling tests, including drop tests from heights up to $4 \mathrm{~m}$. The thermal properties of the fill and WP were measured. Hot-cell tests demonstrated that the fuel assemblies could withstand, with large margins, the WP fill operations without fuel assembly or fuel pin failures. Conceptual designs of facilities to package up to $4700 \mathrm{MTIHM} /$ year have been completed. The space requirements for filling operations in the SNF packaging plant are small compared to the rest of the facility.

The Canadian studies are directly applicable to the U.S. concept of using DU fill in LWR SNF WPs and provides a guide for issues to consider when a WP containing a fill material is used. The fill requirements for use as a structural material in a WP are more severe than those required for DU applications. 


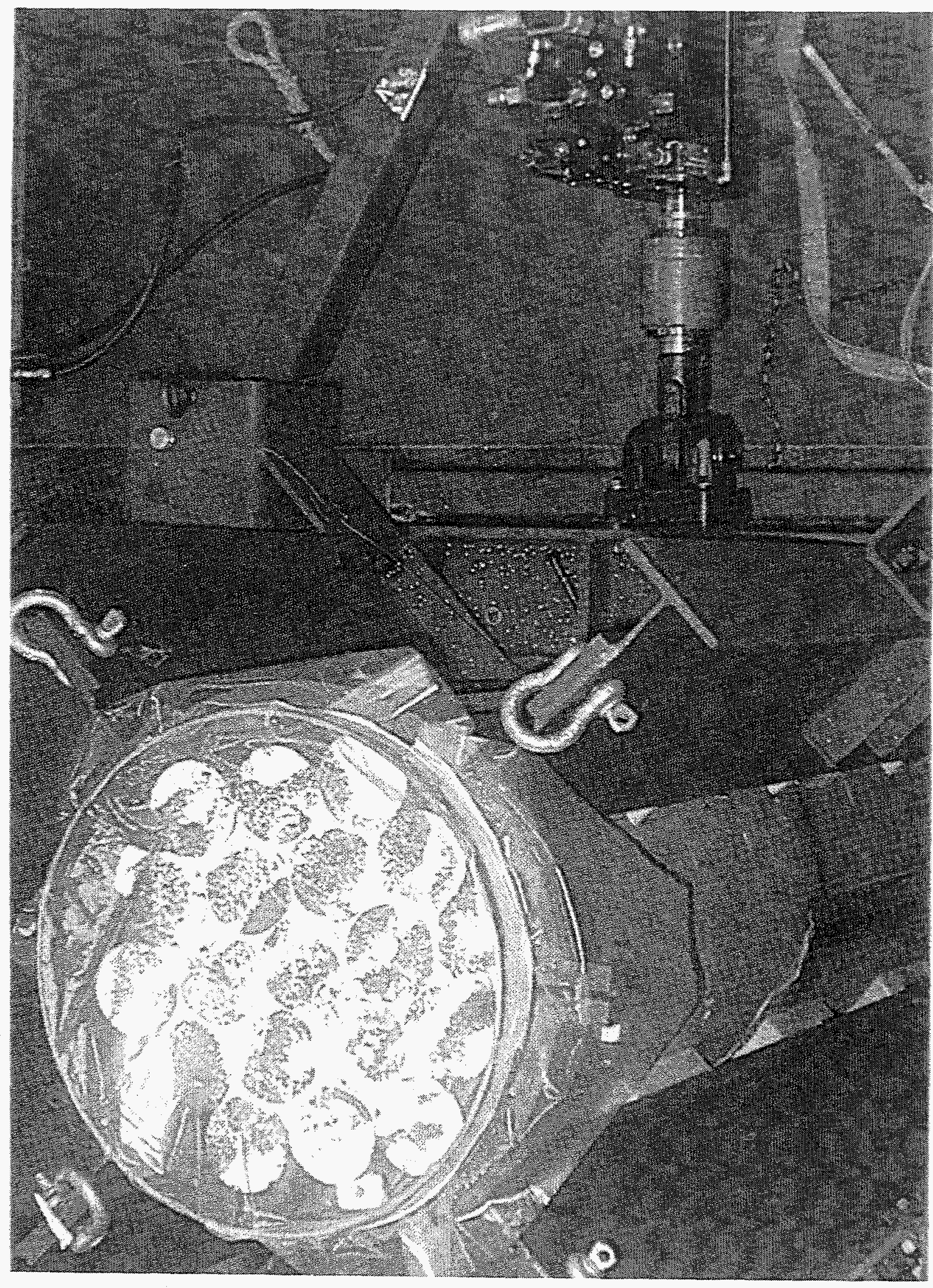

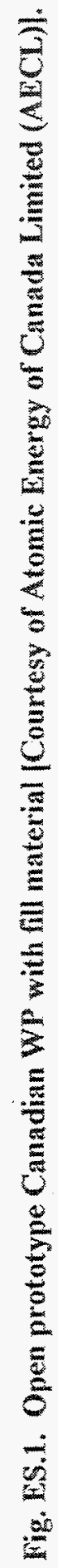




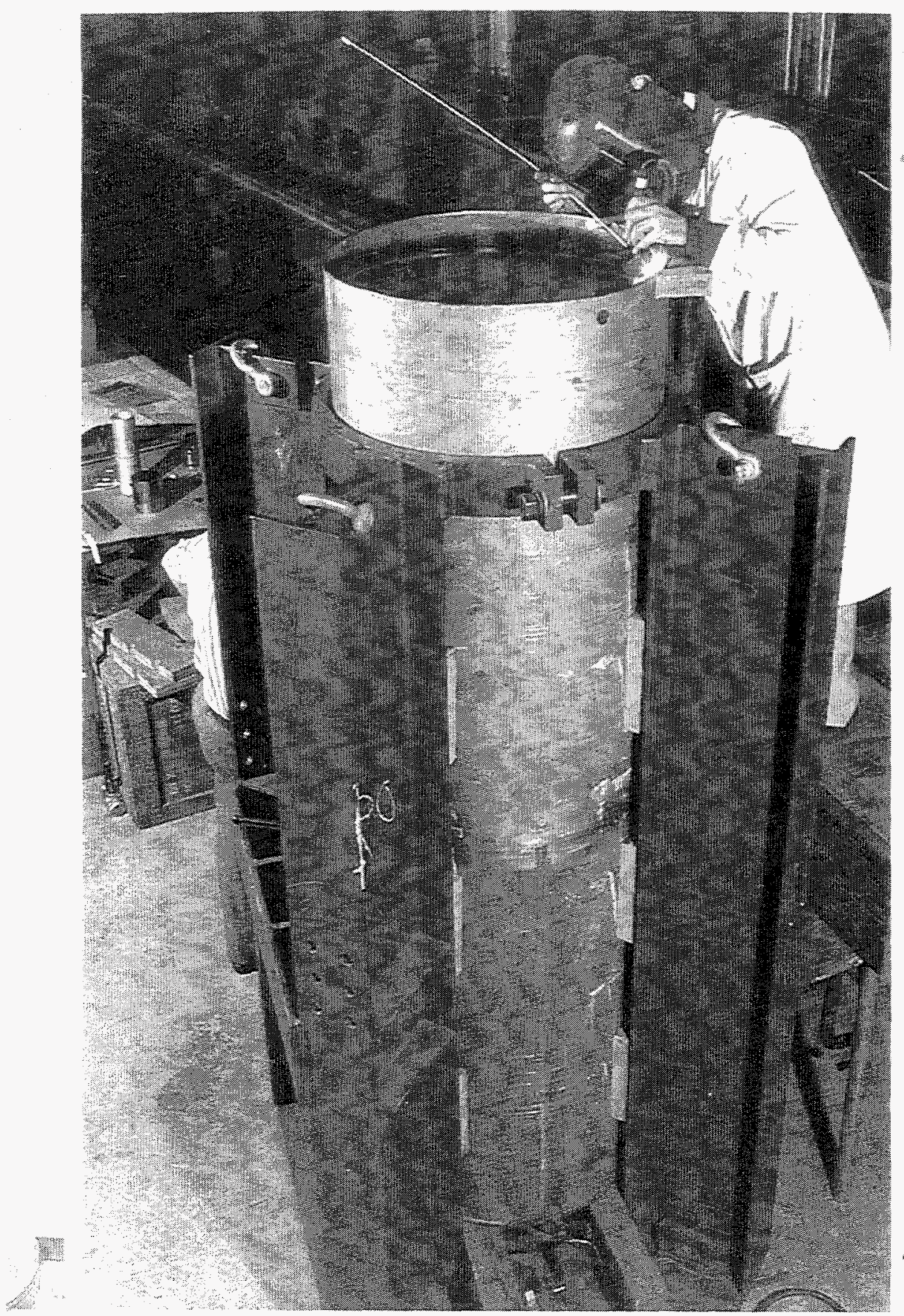

Fig. ES.2. Full-scale prototypic Wh (Courtesy of AECL). 


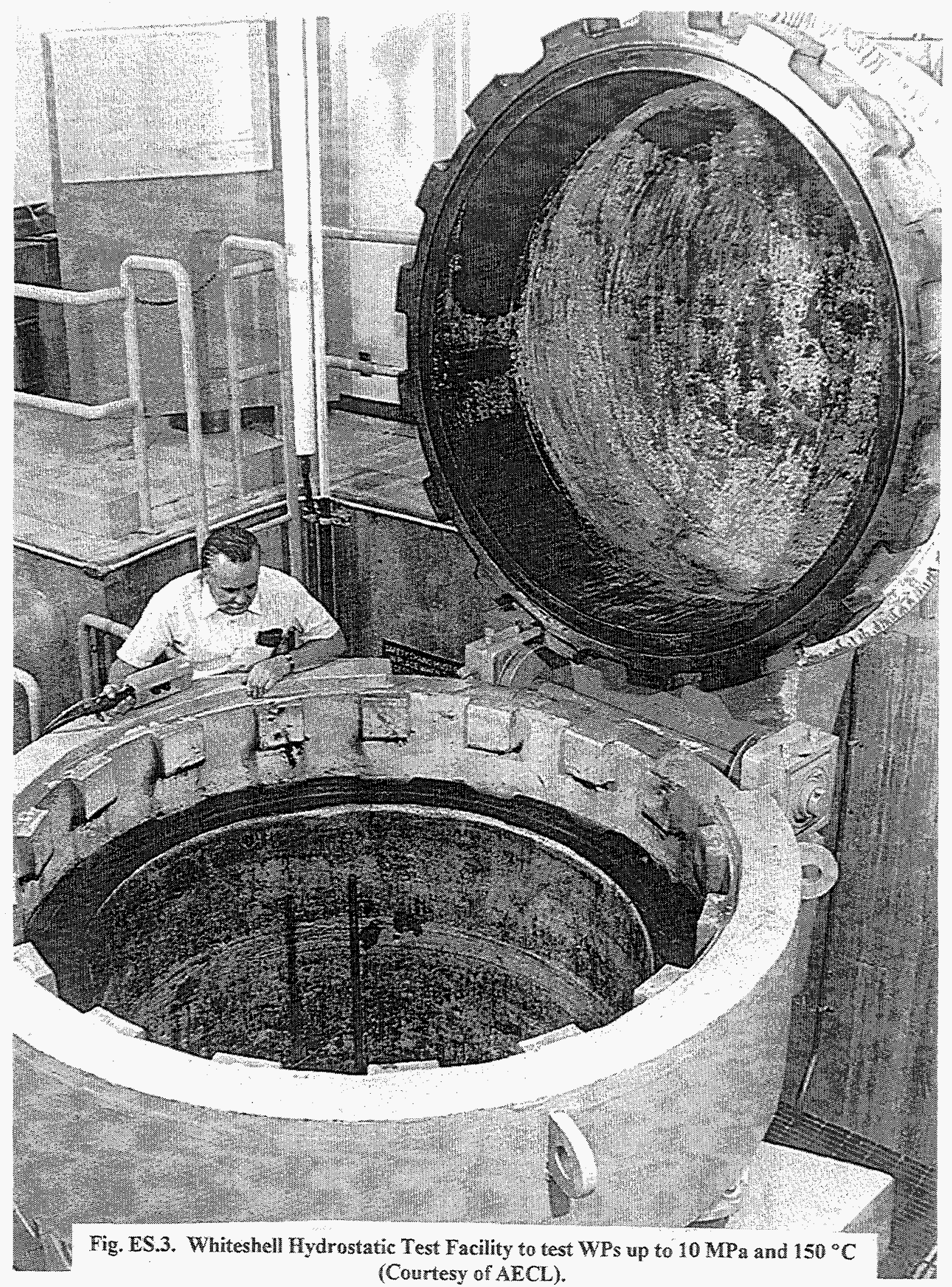




\section{INTRODUCTION}

\subsection{BACKGROUND}

It has been proposed (Forsberg 1995; Forsberg 1996) to use depleted uranium (DU) dioxide $\left(\mathrm{UO}_{2}\right)$ as a fill material in light-water reactor (LWR) spent nuclear fuel (SNF) waste packages (WPs). Empty WPs at the geologic repository are loaded with SNF. The inner void space between the fuel pins and the outer void space between SNF assemblies and the inner WP wall are then filled with small, depleted $\mathrm{UO}_{2}$ particles. The repository WPs are then sealed and placed into the repository.

This concept provides (1) radiation shielding, (2) reduced potential for repository nuclear criticality events, and (3) reduced long-term release of radionuclides from the WP in the repository (see Appendix A). The presence of DU fill allows for the reduction of the radiation exposure to repository workers and to the local geology or reduction in the external WP dimensions. The concept minimizes internal and external nuclear criticality concerns in the repository by reducing the fissile enrichment of the WP to well below $1 \mathrm{wt} \%{ }^{235} \mathrm{U}$ equivalent. Finally, the concept reduces the long-term release of fission products and actinides

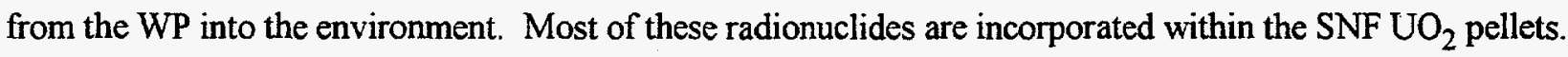
These radionuclides can not be released until the WP fails and the $\mathrm{SNF} \mathrm{UO}_{2}$ crystal structure is destroyed, thus allowing release of trapped radionuclides. The depleted $\mathrm{UO}_{2}$ preferentially reacts with groundwater and suppresses the dissolution of the $\mathrm{SNF} \mathrm{UO}_{2}$ after the WP has failed. This benefit is accomplished by multiple chemical mechanisms: maintenance of chemically reducing conditions within the WP, saturation of the groundwater in the degraded WP with DU, and reduction of degraded WP permeability to air and water flow through the WP. These nuclear and chemical beneficial properties exist only for depleted $\mathrm{UO}_{2}$ fills because only the depleted $\mathrm{UO}_{2}$ has the same chemical form as that of the LWR SNF uranium.

Associated with this concept are uncertainties including the technology required to fill the WP with DU particulates and the mechanical behavior of the WP after filling. There have been extensive theoretical and experimental studies (McGeary 1961; Matthews and Swanson 1979; Schutjens 1991) of fill technology, and many industries (i.e., pharmaceutical, construction, nuclear) use different fill technologies for many applications (Hausner et al. 1967). However, the experience of using fill materials in packages with LWR SNF is limited. One set of proof-of-principle experiments has been done with iron shot (Cogar 1996).

Canada, as part of its waste management program for disposal of CANadian Deuterium Uranium (CANDU) SNF, has developed as one option a titanium, thin-walled WP that uses a compacted particulates to support the external WP walls from outside hydrostatic pressure buildup in the geological repository. This WP system is a result of a 15-year development program. While the functional requirements of the fill material in the Canadian WP are somewhat different from those of a U.S. WP containing DU fill, the large experimental data base developed by the Canadians is directly applicable and useful. 


\subsection{REPORT OBJECTIVES}

The objectives of this report are to review and describe the development of the Canadian WP and the use of fill material in that WP relative to the U.S. efforts to develop a WP for LWR SNF using depleted $\mathrm{UO}_{2}$ as fill material.

\subsection{STRUCTURE OF THE REPORT}

The report is structured into three main sections. Section 2 provides an overview of the Canadian waste management program so the requirements on the Canadian WP are understood. Section 3 describes the development of the WP with its fill material, key experimental data, and key references to the detailed information that is available. Section 4 identifies the information from the Canadian WP program that is applicable to U.S. efforts to develop a WP that would use DU fill. 


\section{THE CANADIAN GEOLOGICAL REPOSITORY SYSTEM FOR DISPOSAL OF CANDU SNF}

\subsection{GENERAL DESCRIPTION}

Both the United States and Canada use nuclear power reactors to generate electricity and have decided to directly dispose of SNF wastes from their reactors in deep geological repositories. A brief description of the similarities and differences of the two programs are provided herein. The differences (Forsberg 1991) in the Canadian and U.S. designs of their proposed geological repositories (Table 2.1) are a consequence of (1) their using different reactor types with different nuclear fuel designs and (2) their choosing different types of geological media for SNF disposal.

Canada uses CANDU reactors (Hart 1994). These are heavy-water-moderated, pressurized-water reactors (PWRs), commonly referred to as heavy-water reactors. The United States uses light-water moderated, PWRs and boiling-water reactors (BWRs). PWRs and BWRs, as a class, are considered LWRs. In all of these reactors, the fuel is $\mathrm{UO}_{2}$, which is contained in zircalloy tubes. The CANDU reactors use natural or slightly-enriched $\left(<0.9 \mathrm{wt} \%{ }^{235} \mathrm{U}\right.$ ) uranium fuel, whereas the LWRs use low-enriched uranium fuel ( 3 to $5 \mathrm{wt} \%{ }^{235} \mathrm{U}$ ). Typical CANDU SNF has burnups (energy production) of 6500 to $9000 \mathrm{Mwd} / \mathrm{metric}$ tons initial heavy metal (MTIHM). The higher-enriched LWR SNF has burnups typically from 30,000 to $50,000 \mathrm{Mwd} / \mathrm{MTIHM}$. These differences in the SNF have two major implications for repository designers.

- The potential for nuclear criticality is essentially nonexistent in the proposed Canadian repository (McCamis 1992) because of the very low concentration of fissile materials in the SNF. Nuclear criticality is a concern [Nuclear Waste Technical Review Board (NWTRB) 1996; NWTRB 1997; Forsberg 1997] in the design of a U.S. repository because of the higher fissile content of the SNF.

- The Canadian SNF has a lower burnup and produces less energy per ton of SNF than does LWR SNF. As a direct consequence, large quantities of SNF must be managed. For the nuclear generating capacity considered in the conceptual design studies (Simmons and Baumgartner 1994), the proposed Canadian repository would dispose of $191,000 \mathrm{t}$ compared to the 87,900 $\mathrm{t}$ of LWR SNF to be disposed of in the United States [U.S. Department of Energy (DOE) December 1996].

Canada and the United States have chosen different geological media for their repositories. The Canadian repository will be in granite in the Canadian Shield, which is a geological structure in the middle of Canada that stretches from the Arctic Ocean south within the United States to Minnesota, Wisconsin, and Michigan. The expected repository depths will be between 500 and $1000 \mathrm{~m}$. The granite is saturated with water, and the repository will be below the water table; thus, any WP within the repository must ultimately resist the hydrostatic pressure from the groundwater. Also, the granite has chemically reducing conditions. The proposed U.S. repository is at Yucca Mountain in Nevada and will, when built, be in tuff, which is consolidated volcanic ash. The expected repository depth is $\sim 300 \mathrm{~m}$. The site is dry (i.e., the proposed repository is above the water table) with no hydrostatic pressure on the WP. The tuff has chemically oxidizing conditions. 
Table 2.1. Conceptual designs of the Canadian and U.S. geological repository systems

\begin{tabular}{|c|c|c|}
\hline \multirow[b]{2}{*}{ Characteristic } & \multicolumn{2}{|c|}{ Country } \\
\hline & Canada & United States \\
\hline \multicolumn{3}{|l|}{ General } \\
\hline Geology & Granite & Tuff \\
\hline Depth, $\mathrm{m}$ & $500-1000$ & 300 \\
\hline Location & Below water table & Above water table \\
\hline \multicolumn{3}{|l|}{ Waste package } \\
\hline Type & Thin-wall titanium & Thick-wall steel \\
\hline Assemblies per WP & 72 & 21 \\
\hline Length, $\mathrm{cm}$ & 224.6 & 533.5 \\
\hline Diameter, $\mathrm{cm}$ & 63.3 & 162.9 \\
\hline \multicolumn{3}{|l|}{ SNF } \\
\hline Potential quantity, MTIHM & 191,000 & 87,900 \\
\hline Type & CANDU & PWR \\
\hline Fuel & $\mathrm{UO}_{2}$ & $\mathrm{UO}_{2}$ \\
\hline Clad & Zircalloy & Zircalloy \\
\hline Cross section & Cylindrical & Square \\
\hline Assembly width (diameter), $\mathrm{cm}$ & 10.2 & 21.4 \\
\hline Assembly height, $\mathrm{m}$ & 0.495 & 4.063 \\
\hline
\end{tabular}

Source: Johnson April 1994.

The structure of the Canadian program is defined by the Canadian Nuclear Fuel Waste Management Program, which is a joint program of the government of Canada and the province of Ontario. Atomic Energy of Canada Limited (AECL) is the lead agency for research on disposal. Ontario Hydro, the Canadian electric utility that operates most of the Canadian nuclear power plants, provides significant technical assistance to this effort. The structure of the U.S. program is defined by the Nuclear Waste Policy Act. DOE has responsibility for implementing the program. 


\subsection{SNF}

The fuel assemblies for CANDU reactors (Fig 2.1) and LWRs (Fig. 2.2) are different; but the fuel pins, materials of construction, and many other features are similar for both fuel assemblies (Table 2.2). Figure 2.3 shows a cross section of a CANDU and PWR fuel assembly. LWR fuel assemblies have grids to hold pins in place. The CANDU fuel assemblies have spacers attached to the fuel-pin clad. Such similarities are expected because both reactor types are water cooled and have similar thermal-hydraulic constraints in their reactor cores.

The internal dimensional clearances between pins within the CANDU fuel assembly, on average, are smaller than those of LWR assemblies. The minimum clearance between rods in a CANDU fuel assembly is $1.3 \mathrm{~mm}$ vs $3.4 \mathrm{~mm}$ for a standard PWR fuel assembly. This is expected to make filling the void spaces within CANDU fuel assemblies somewhat more difficult than filling the void spaces within LWR fuel assemblies. Sixty-one percent of the cross section of the CANDU fuel assembly is composed of pins whereas only $41 \%$ of the cross section of a PWR fuel assembly is composed of pin.

\subsection{WP}

\subsubsection{U.S. WP with Depleted $\mathrm{UO}_{2}$ Fill}

The proposed U.S. repository system consists of several components. The geological repository is located $\sim 300 \mathrm{~m}$ underground in tuff. Horizontal drifts (tunnels) will be constructed to hold the WPs, which are to be placed horizontally in the tunnels (Fig. 2.4). Ultimately, the space around the WP may be backfilled with tuff or an equivalent material to reduce the potential for rockfalls and for water flow to the WP.

The alternative proposed WP (Table 2.3) with DU fill would be essentially identical to the current baseline, Yucca Mountain WP design (Dyer and Voegele September 1996) without fill material. The package is designed to hold 21 PWR fuel assemblies. The WP is a heavy-wall, steel package with an inner layer of corrosion-resistant steel alloy and an outer layer of sacrificial steel that cathodically protects the inner steel alloy against corrosion. The DU fill provides (1) additional shielding, (2) a reduction in the potential for repository nuclear criticality events, and (3) a reduction in the long-term release of radionuclides from the WP in the repository.

\subsubsection{Canadian WP System}

The Canadian repository system consists of several components. In one concept (Simmons and Baumgartner 1994), the geological repository is to be located 500 to $1000 \mathrm{~m}$ underground in granite below the water table. Horizontal drifts (tunnels) are to be constructed to hold the WPs, which are placed in boreholes (Fig. 2.5). Surrounding each WP is a bentonite clay material that minimizes water flow into the WP, controls WP near-field geochemistry, and absorbs radionuclides that could be eventually released from the WP. Beyond the buffer is the backfill that holds the buffer and WPs in place and fills all void space in the repository. 


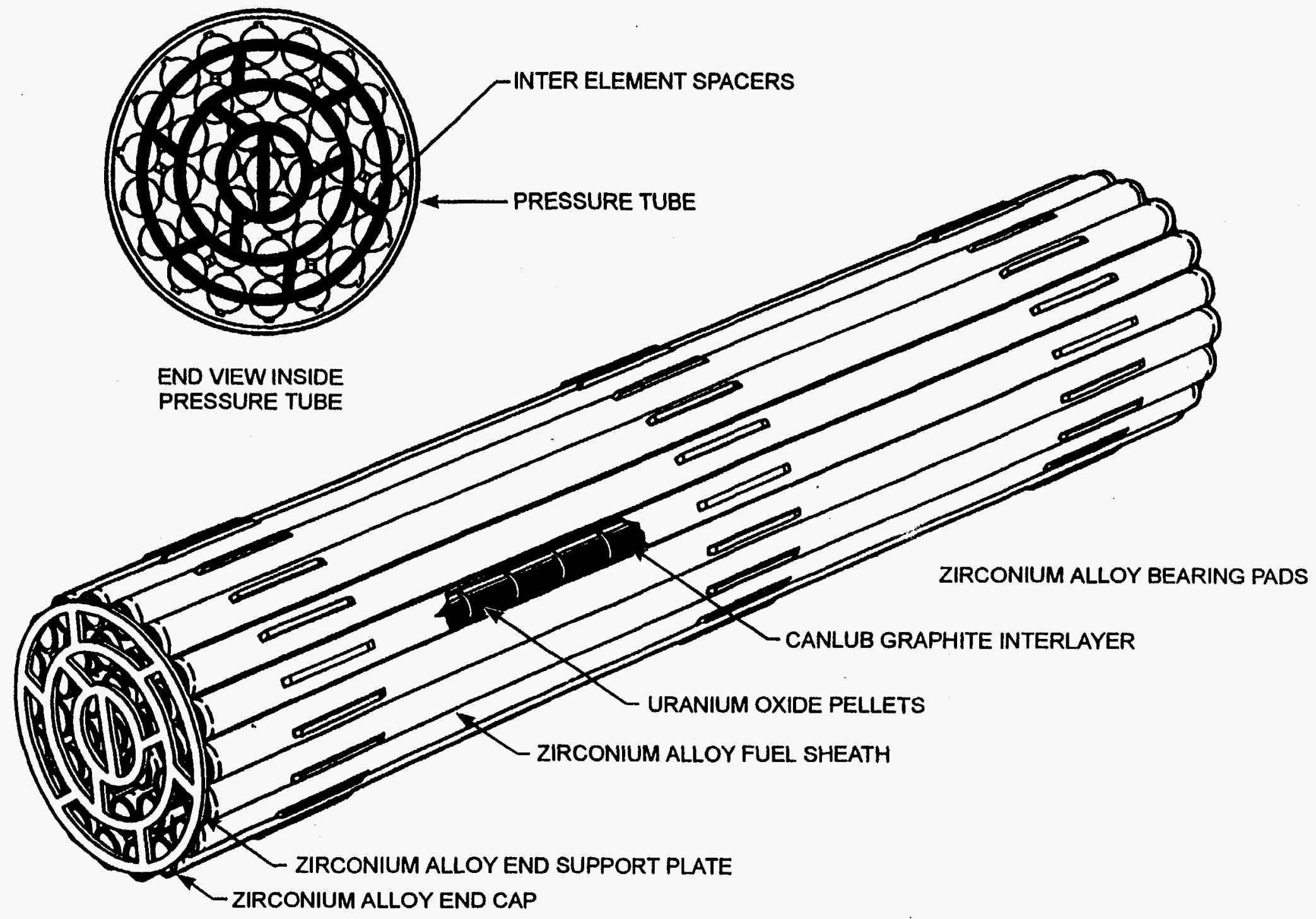

Fig. 2.1. CANDU fuel assembly (Courtesy of AECL). 
ORNL DWG 85-838

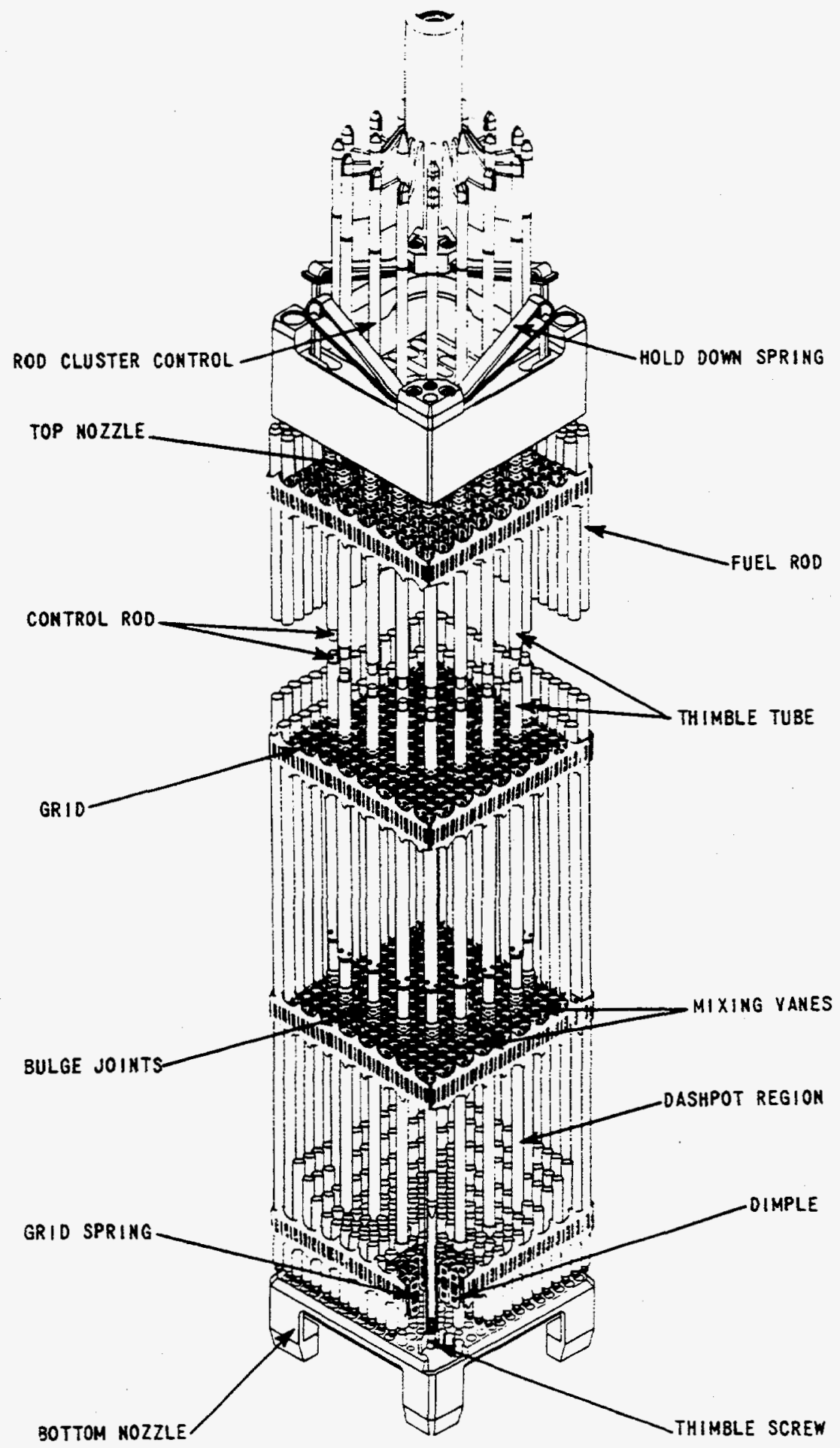

Fig. 2.2. PWR fuel assembly. 
8

Table 2.2. Characteristics of CANDU and PWR SNF

\begin{tabular}{|c|c|c|}
\hline \multirow[b]{2}{*}{ Property } & \multicolumn{2}{|c|}{ Fuel-assembly type } \\
\hline & CANDU & $\mathbf{P W R}^{\mathbf{a}}$ \\
\hline Weight, kg & 21.2 & 611.5 \\
\hline Uranium, $\mathrm{kg} / \mathrm{assembly}$ & 19 & 401. \\
\hline Initial enrichment, ${ }^{235} \mathrm{U}$ wt \% & $0.71-0.9$ & $3-5$ \\
\hline Burnup, $M W d / t$ & 6,850 (design) & $30,000-50,000$ \\
\hline \multicolumn{3}{|l|}{ Assembly } \\
\hline Geometry & Circular & Square \\
\hline Length, $\mathrm{m}$ & 0.495 & 4.063 \\
\hline Width (diameter), $\mathrm{cm}$ & 10.2 & 21.4 \\
\hline Fuel pins, number & 37 & 264 \\
\hline Nonfuel pins/tubes, number & 0 & 25 \\
\hline Ratio of pin area to total area & 0.613 & 0.414 \\
\hline Minimum pin gap, mm & 1.3 & 3.4 \\
\hline \multicolumn{3}{|l|}{ Pins } \\
\hline Fuel type & $\mathrm{UO}_{2}$ & $\mathrm{UO}_{2}$ \\
\hline Clad type & Zircalloy & Zircalloy \\
\hline Length, $\mathrm{m}$ & 0.493 & 3.868 \\
\hline Diameter, $\mathrm{cm}$ & 1.3 & 0.914 \\
\hline Clad thickness, mm & 0.4 & 0.57 \\
\hline Spacers (grids) & 3 & 6 \\
\hline
\end{tabular}

${ }^{\text {a The }} 17 \times 17$ PWR fuel assembly has a total of 289 rod positions. Twenty-five positions may contain guide tubes for control rods, instrument tubes, and/or burnable absorber rods. 
ORNL DWG 97C-283

CANDU Fuel

Pin Arrangement

Fuel Pin

Guide Tube

Instrument Tube

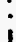

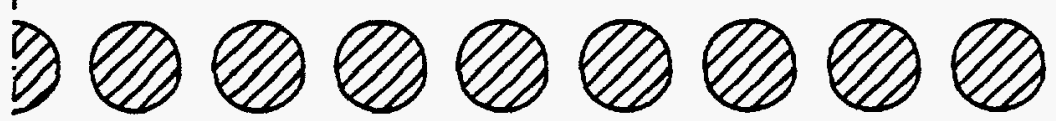

300

i)

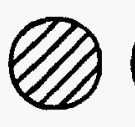

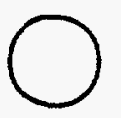

$Q$

$Q$

Q

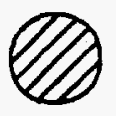

Q

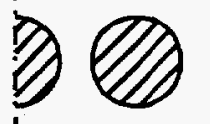

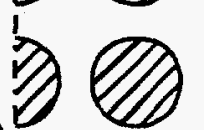

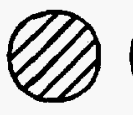

$Q$

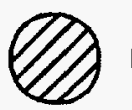

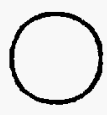

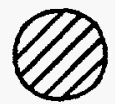

Q

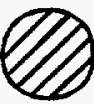
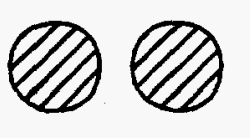

$Q$

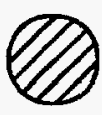

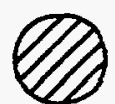

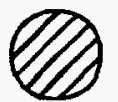

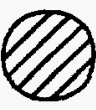
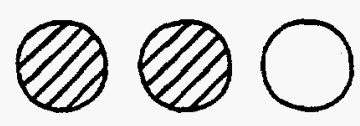

$\theta$

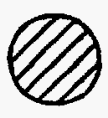

0

$\theta$

$\theta$

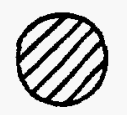

$Q$
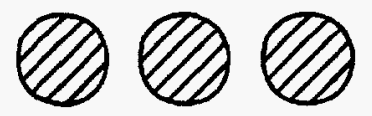

$Q$

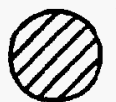

$\theta$

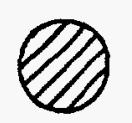

$Q$

$\theta$

$Q$

$\theta$

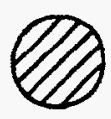

Q

$\theta$
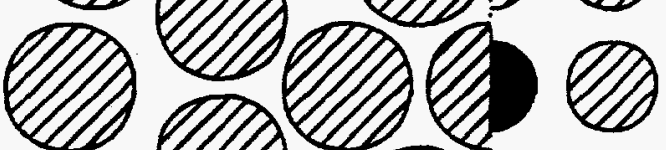

$Q$
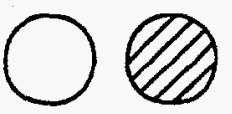

$\theta$

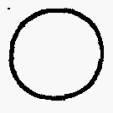

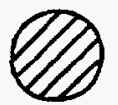

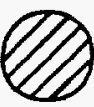

$\theta$

$\theta$

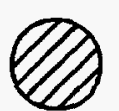

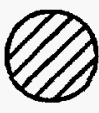

Q

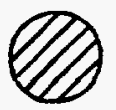

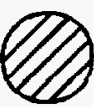

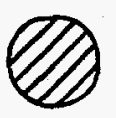
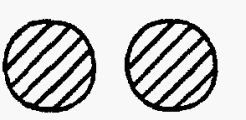

$\theta$

$\theta$

$\theta$

$\theta$
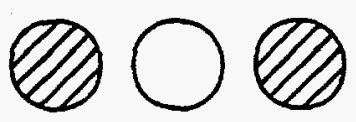

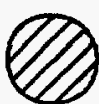

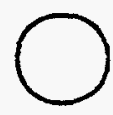

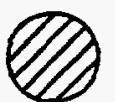

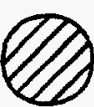

$\theta$

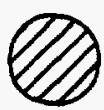

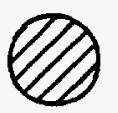

$Q$

$Q$

$\theta$

$Q$

b

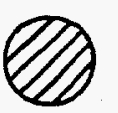

$\Leftrightarrow$

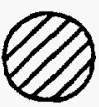

$\theta$

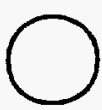

$\theta$

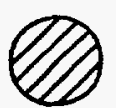

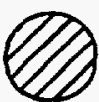

Scale

o $1.27 \quad 2.54(\mathrm{~cm})$

$0 \quad 0.5 \quad 1.0$ (in)
)

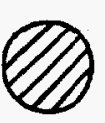

$\theta$

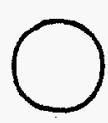

$\theta$

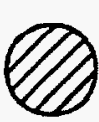

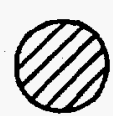

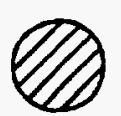

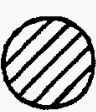

$\eta$

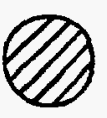

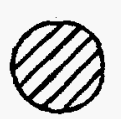

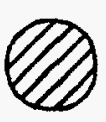

$\theta$

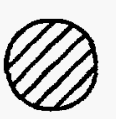

Q

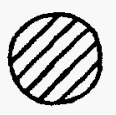

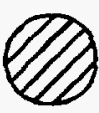

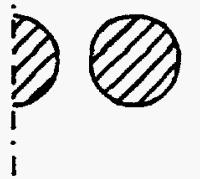

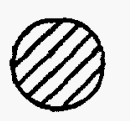

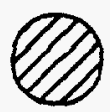

$\theta$
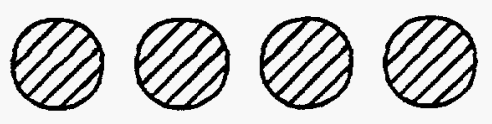

Fig. 2.3. Cross sections of CANDU and PWR fuel assemblies. 
ORNL DWG 97-248

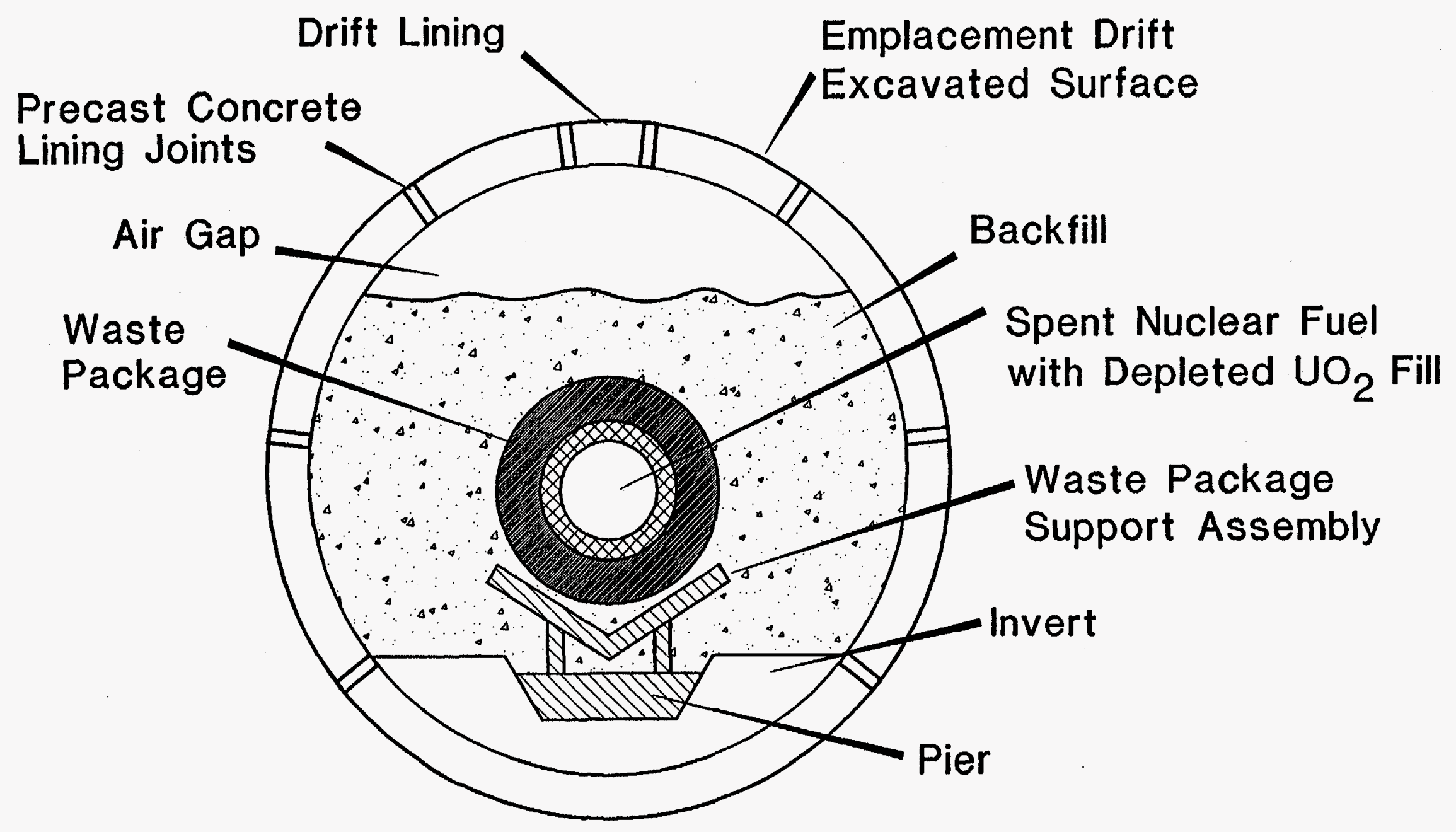

Fig. 2.4. LWR WP emplacement inside the U.S. repository. 
Table 2.3. Conceptual Canadian and U.S. WP designs that use fill materials

\begin{tabular}{lll}
\hline & \multicolumn{2}{c}{ Country } \\
\cline { 2 - 3 } Characteristics & Canada & United States \\
\hline Status & Design option & Design option \\
WP material of construction & Titanium-2 & Steel \\
Fill material & High-silica glass beads & Depleted UO 2 \\
Assemblies per package & 72 & 21 \\
Levels per WP & 4 & 1 \\
Assemblies per level & 18 & 21 \\
Diameter, cm & 63.3 & 162.9 \\
Length, cm & 224.6 & 533.5 \\
Wall thickness, mm & 6.35 & \\
Buffer around package & yes & no \\
Basket structure & & \\
Form & Tube bundle & Square box bundle \\
Material & Steel & Steel \\
Thickness (mm) & 3.2 & \\
\hline
\end{tabular}

Sources: Crosthwaite 1994; Forsberg 1996; Dyer 1996; Johnson et al. April 1984.

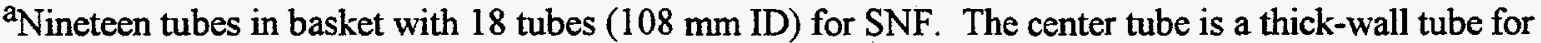
handling the internal basket during transfer operations. 


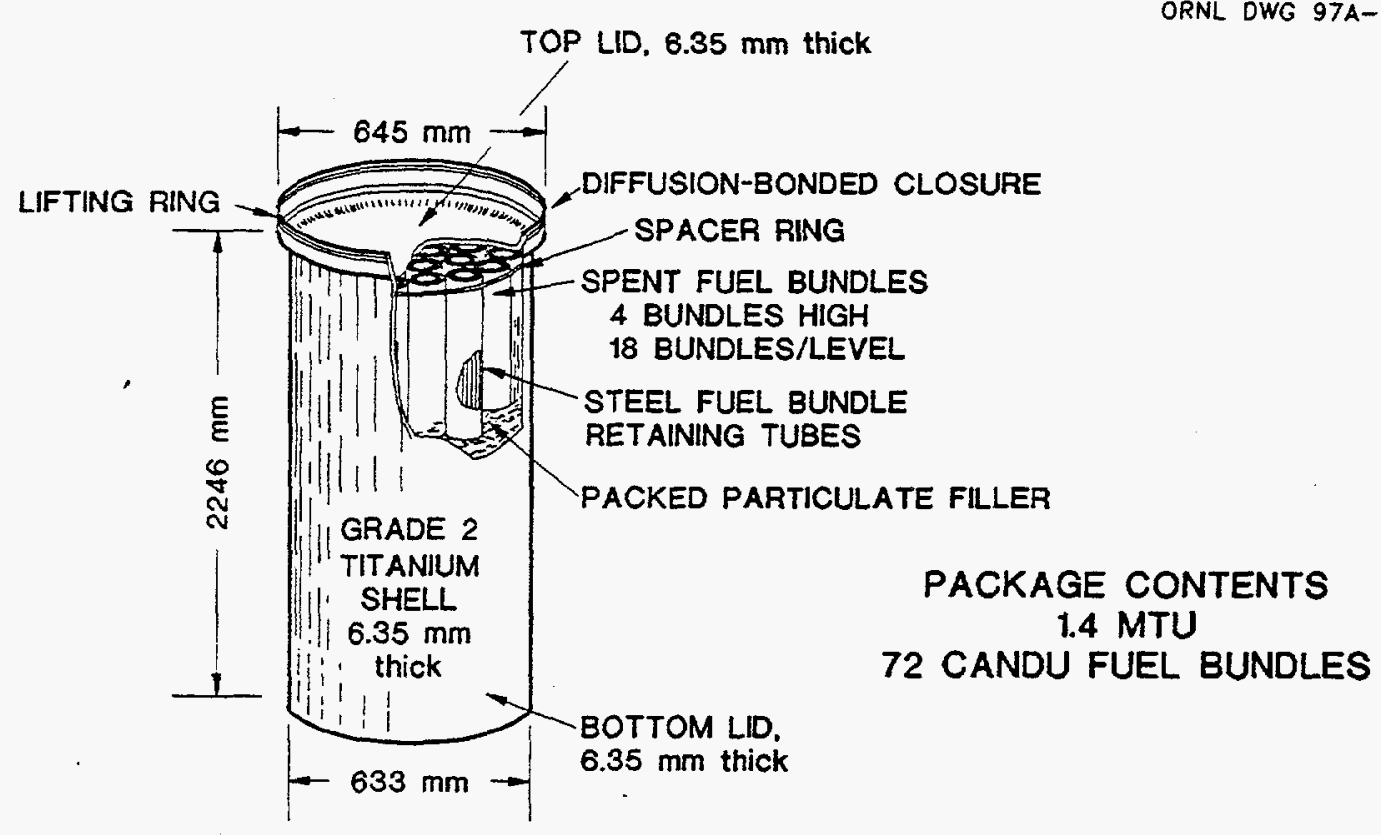

\section{CANISTER CONCEPT}

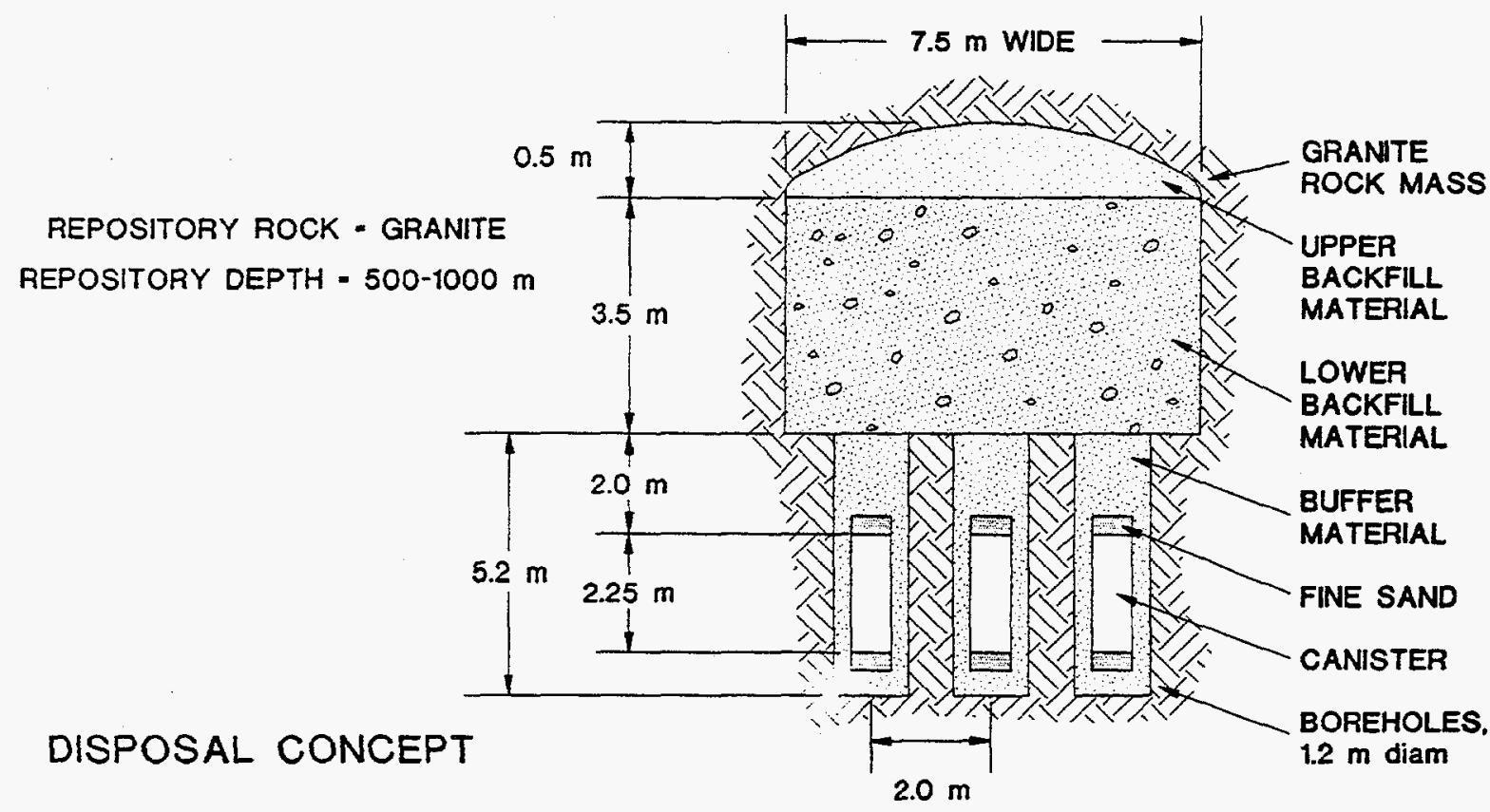

ITRANSVERSE CROSS SECTION THROUGH EMPLACEMENT DRIFT)

Fig. 2.5. One Canadian concept for CANDU SNF WPs and for disposal of WPs in granite. 
The WP (Johnson April 1994) is made of American Society for Testing and Materials grade-2 titanium, which was chosen because of its long-term resistance to corrosion (Allen and Simmons 1996). At depths in the proposed Canadian repository, long-term hydrostatic pressure from groundwater reentering the repository after closure may equal $10 \mathrm{MPa}(\sim 100 \mathrm{~atm})$ on the exterior of the WP. To prevent WP collapse and subsequent wall failure, the thin external wall of the WP must be supported. Supporting the WP wall also supports the bentonite barrier (buffer) to radionuclide migration that is exterior to the WP. In one concept, the container wall is supported by high-silica, low-sodium glass beads or silica sand that totally fill the WP empty void spaces. This WP option is designed to hold 72 CANDU fuel assemblies. 



\section{CANADIAN WP DEVELOPMENT PROGRAM}

Canada has conducted a 15-year development program for its repository that led to development of alternative WPs. Canada adopted the following strategy (Crosthwaite 1994):

"Early in the development studies, it was concluded that the most credible approach to developing and evaluating container designs was to carry out a program that included fabrication and inspection technology development, prototype fabrication, structural proof testing, and structural-performance modeling. This would allow:

1. the development and demonstration of fabrication and inspection techniques that would be required for production;

2. direct measurement of the structural performance of candidate container designs;

3. the opportunity to test the validity of structural-performance predictions obtained from computer modeling and stress analysis; and

4. evaluation of the sensitivity of the structural behavior of various container designs to tolerances in these design specifications."

The results of the packed-particulate container development program are described below. Much of the detailed development of the container was performed by Ontario Hydro.

\subsection{SELECTION OF FILL}

The requirements for the Canadian WP fill material are that it fill all empty spaces within the WP, is chemically inert, is structurally strong, and is inexpensive. The fill is required to support the WP wall against $10 \mathrm{MPa}$ of external hydrostatic pressure.

An extensive test program was initiated to define the preferred fill material (Teper 1980; Teper 1981 $a$; Teper 1981 b; Teper 1982; Teper 1986a: Teper 1987a; Teper 1987b; Mikasinovic and Teper 1981; Mikasinovic and Hoy 1982; Shelson 1983). Twelve fill materials were investigated including Wedron sand ( 0.2 to $0.85 \mathrm{~mm})$, coarse glass beads $(0.8$ to $1.2 \mathrm{~mm})$, fine glass beads $(0.02$ to $0.3 \mathrm{~mm})$, steel shot ( 0.6 to $1.0 \mathrm{~mm}$ ), and bauxite grains (up to $1 \mathrm{~mm}$ ). Compressive strength was measured. Extensive fill tests were conducted using the large Ontario Hydro seismic shake table to define the particle size, vibration frequencies, and accelerations that provided the most rapid and reliable filling of the WP and fuel assemblies.

Initial tests were conducted on a stack of two simulated CANDU fuel assemblies (Fig. 3.1) with the fuel assemblies offset to provide the maximum resistance to particulate filling of void spaces in the lower fuel assembly. Figure 3.2 shows one run during which the void space was first filled by the gravity flow of the 

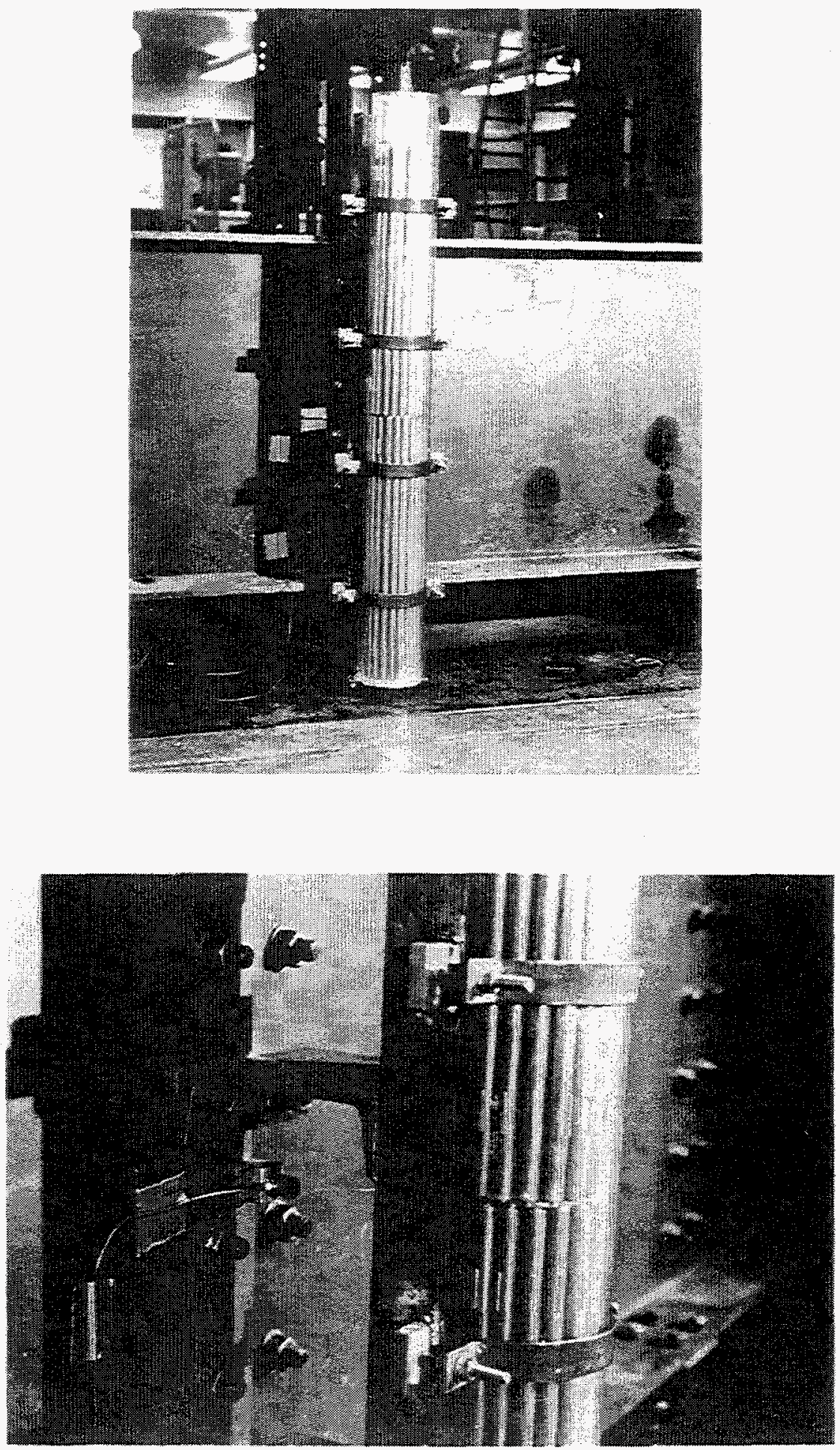

Fig. 3.1. Two-nuclear-fuel assembly particulate fil test on the Ontario Hydro large seismic shake table (Courtesy of AECL). 

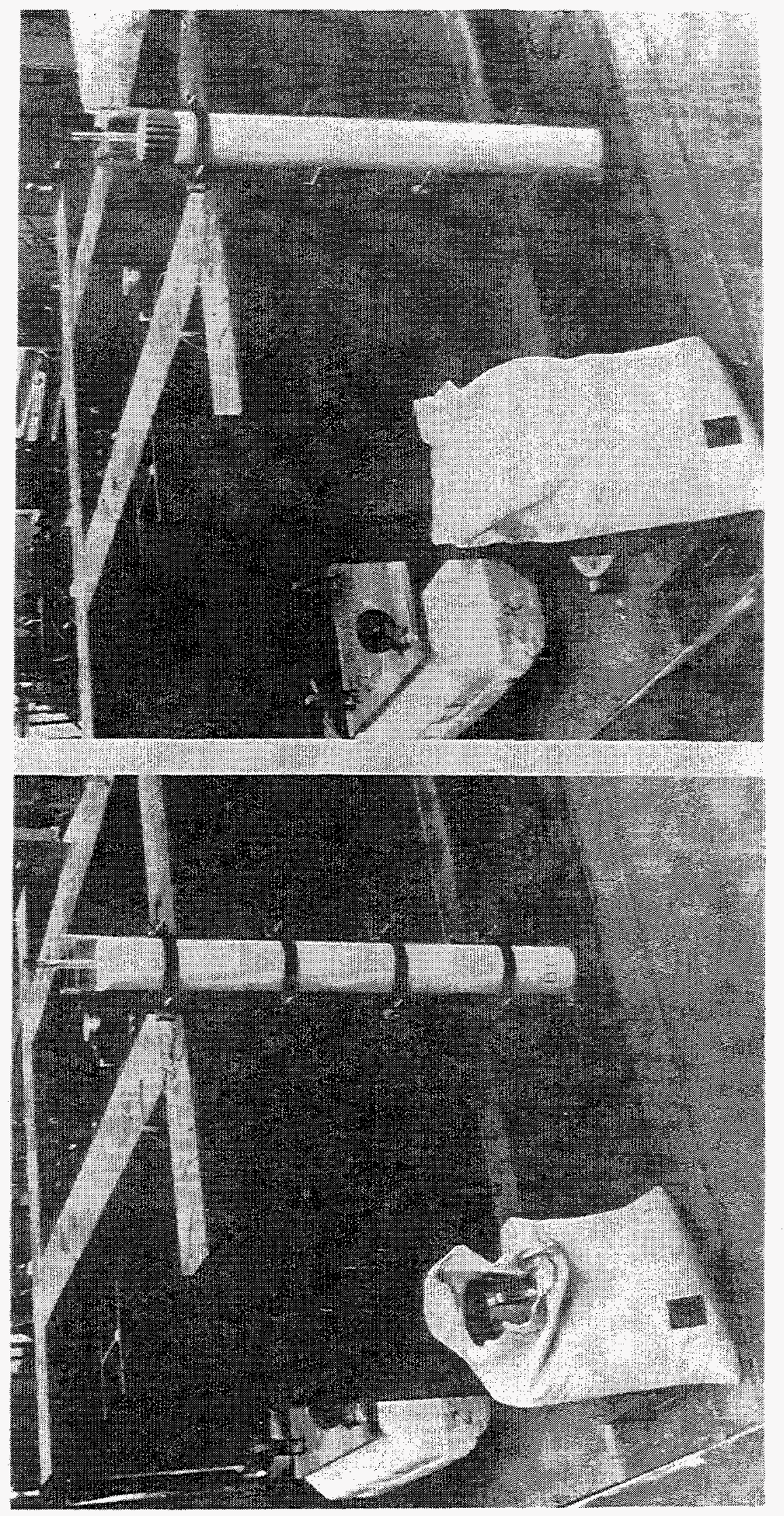

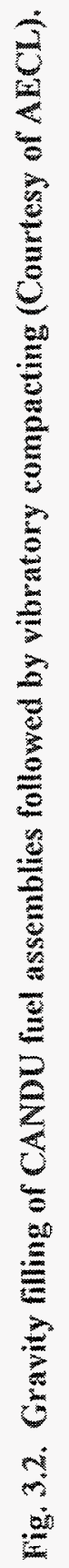


particulates followed by vibratory compaction and further consolidation of the fill material. Typically, the "as poured" fill has a density of 80 to $90 \%$ of the reference density (see below) with improved densities after vibratory compaction. The test results provided confidence that the fill material would go both between the rods and through fuel assembly end fittings that were misaligned with respect to particulate flow. The tests further showed that both particulates made of small smooth spheres and particulates with rough surfaces (sand) would fill the assemblies. Later tests were conducted on a full-scale prototype WP (Fig. 3.3). Table 3.1 shows the results of one set of runs.

Moderate vibration significantly improves fill density and reduces filling times. When a WP is vibrated, the fill becomes a "fluid" and enters void spaces where the particulate fill can only enter by horizontal channels or from the bottom. In contrast, if the fill is poured into the WP without vibration, only the void spaces that can be filled from the top of the WP are fully filled. Vibration has the added benefit of reducing the time required to load a WP with particulates. Because of these factors, the decision to vibrate a WP and the filling conditions depend upon both the required final fill density for the void spaces and potential economic advantages of shorter fill times.

The success of a filling operation is measured by the fill fraction or percentage. This is defined as the void space filled with particulates divided by the void space that would be filled with particulates assuming ideal packing of the particulate fill. For uniform spheres in a face-centered cubic array, the spheres would occupy $74.048 \mathrm{vol} \%$ of the void space. A particulate packing fraction of $100 \%$ implies that $74.048 \mathrm{vol} \%$ of the void space is filled with solid particulate and the remainder of the space is unavoidable void space between particulates. Higher fill fractions are possible if particulates with multiple sizes are used so the small particulates can fill the empty spaces between the larger particles.

In the prototype WP, simulated fuel assemblies were included in the outer basket ring to simulate the added stiffness provided by the fuel assemblies to the WP after filling was completed. The WP was welded shut, and the welds were inspected to ensure they met the requirements of the American Society of Mechanical Engineers (ASME) Boiler and Pressure Vessel Code (Maak 1985).

Two materials are being considered: industrial glass beads with a diameter of $\sim 1 \mathrm{~mm}$ and silica sand. Tests indicated that for the specific WP design, the WP should be vibrated for $15 \mathrm{~min}$. at $50-60 \mathrm{~Hz}$ with a peak-to-peak acceleration of $39.3 \mathrm{~m} / \mathrm{s}^{2}$. These conditions provided high confidence for a complete filling of the WP (Crosthwaite 1994). 


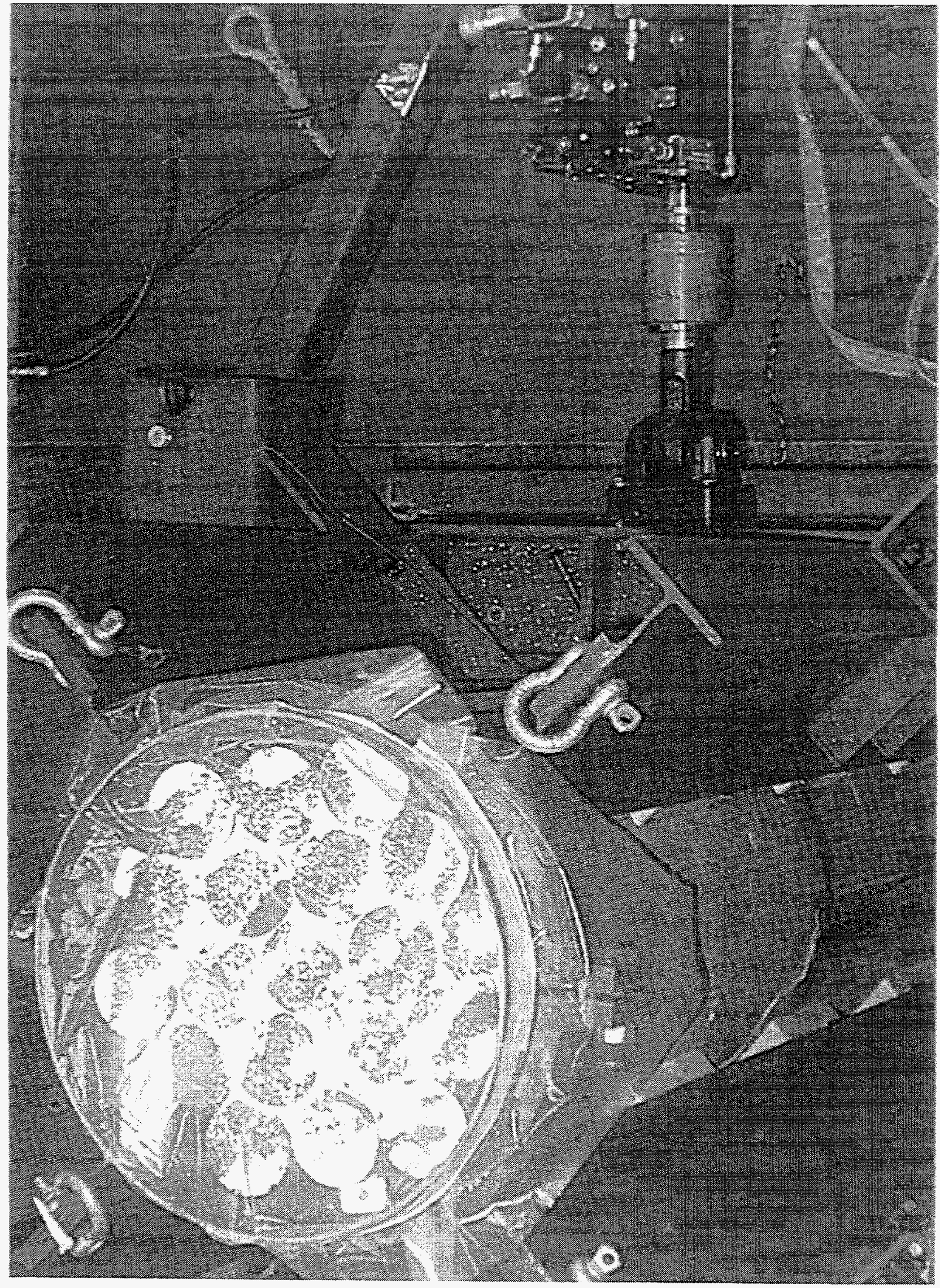

Fig. 3.3. WP multiassembly particulate fil test. 
Table 3.1. Results of vibratory compaction tests ${ }^{1}$

\begin{tabular}{|c|c|c|c|c|c|c|c|c|c|c|}
\hline Test no. & $\begin{array}{c}\text { Type of } \\
\text { particulate }\end{array}$ & $\begin{array}{c}\text { Reference } \\
\text { density }^{2} \\
\rho_{\mathrm{r}}(\mathrm{kg} / \mathrm{L}) \\
\end{array}$ & $\begin{array}{c}\left(\rho / \rho_{\mathrm{r}}\right) \\
\mathrm{MAX} \\
(\%) \\
\end{array}$ & $\begin{array}{c}\text { Density } \\
\text { of } \\
\text { pouring } \\
\rho(\mathrm{kg} / \mathrm{L}) \\
\end{array}$ & $\begin{array}{l}\text { First } \\
\text { freq. } \\
(\mathrm{Hz}) \\
\end{array}$ & $\begin{array}{l}\text { Density } \\
\rho(\mathrm{kg} / \mathrm{L})\end{array}$ & $\begin{array}{c}\text { Second } \\
\text { freq. } \\
(\mathrm{Hz})\end{array}$ & $\begin{array}{l}\text { Density } \\
\rho(\mathrm{kg} / \mathrm{L}) \\
\end{array}$ & $\begin{array}{l}\text { Third } \\
\text { freq. } \\
\text { (Hz) }\end{array}$ & $\begin{array}{l}\text { Density } \\
\rho(\mathrm{kg} / \mathrm{L}) \\
\end{array}$ \\
\hline 1 & Sand & 1.932 & 84.7 & 1.58 & 10 & 1.624 & 80 & 1.637 & 150 & 1.637 \\
\hline 2 & $\begin{array}{l}\text { Sand-bundles } \\
\text { not included }\end{array}$ & 1.932 & 87.0 & 1.55 & 60 & 1.680 & & & & \\
\hline 3 & Sand & 1.932 & 89.1 & 1.56 & 30 & 1.710 & 60 & 1.715 & 120 & 1.72 \\
\hline 4 & Sand & 1.932 & 89.0 & 1.55 & 150 & 1.72 & 70 & 1.72 & 25 & 1.72 \\
\hline 5 & $\begin{array}{c}\text { Fine glasss } \\
(0.002-0.3 \mathrm{~mm} \text { diam. })\end{array}$ & 1.780 & 97.8 & 1.60 & 25 & 1.70 & 90 & 1.73 & 180 & 1.74 \\
\hline 6 & $\begin{array}{c}\text { Fine glass } \\
(0.002-0.3 \mathrm{~mm} \text { diam. })\end{array}$ & 1.780 & 98.9 & 1.61 & 100 & 1.75 & 45 & 1.76 & & \\
\hline 7 & $\begin{array}{c}\text { Glass beads } \\
(0.8-1.2 \mathrm{~mm} \text { diam. })\end{array}$ & 2.21 & 91.4 & 1.94 & 40 & 2.02 & 110 & 2.03 & & \\
\hline 8 & $\begin{array}{c}\text { Glass beads } \\
(0.8-1.2 \mathrm{~mm} \text { diam. })\end{array}$ & 2.221 & 91.4 & 1.97 & 90 & 1.03 & 45 & 2.03 & & \\
\hline
\end{tabular}

${ }^{1}$ Source: Teper 1982; Teper 1986.

${ }^{2}$ Reference density $\left(\rho_{r}\right)$ refers to the maximum density of uniform spheres in a face-centered cubic array. The reference density is $0.74048 \times$ solid bulk density of the particulates for a single, uniform particle size. 


\subsection{FULL-SCALE WP TESTS FOR REPOSITORY CONDITIONS}

The prototype WP was hydrostatically tested at the Hydrostatic Test Facility at the Whiteshell Laboratories of AECL (Fig. 3.4). This facility was built to test WPs under expected repository conditions. Testing was at $10 \mathrm{MPa}$ and $150^{\circ} \mathrm{C}$, a temperature that is $50^{\circ} \mathrm{C}$ higher than the maximum expected in the repository. The successful test demonstrated that no significant voids were found in the WP (Teper 1985; Teper 1987b; Teper 1988a; Teper and Reid 1989). Subsequent tests measured WP behavior (after various quantities of fill were removed) to identify the effects of leaving void spaces within the WP. With small voids, the package was significantly deformed, but it did not fail. A parallel analytical program demonstrated the capability to predict the consequences of various types of filling failures (Teper 1986; Teper 1988b).

\subsection{WP TRANSPORT AND HANDLING TESTS}

Drop tests $(0.1$ to $4.0 \mathrm{~m})$ were conducted on the filled prototype to determine its characteristics under accidental conditions. The WP did not fail (Teper 1991). The fill provided the required structural support for the WP.

\subsection{SNF MECHANICAL TESTS}

Vibration and impact tests were conducted on CANDU SNF (Forest 1980, Forest 1985; Wasywich 1993). These tests allowed evaluation of the potential for SNF damage during particle filling operations. The CANDU fuel assemblies have somewhat thinner clad than typical LWR SNF. Bundles withstood decelerations of $766 \mathrm{~m} / \mathrm{s}^{2}$ in the lateral direction and $1718 \mathrm{~m} / \mathrm{s}^{2}$ in the axial direction. Fatigue tests indicated that the bundles would have to be shaken for $\sim 24 \mathrm{~h}$ under the filling process conditions (nominally for $15 \mathrm{~min}$.) before failure would occur.

\subsection{RECOVERY FROM WP MANUFACTURING FAILURE}

The potential exists for the WP to fail during loading operations. Problems with welds or serious handling accidents may make the WP unacceptable to use for final disposal of SNF. In such a case, the following approach is planned (AECL CANDU April 1992; Simmons and Baumgartner 1994 ): (1) the defective WP is placed on a rotary table, (2) the top and bottom ends are separated with an abrasive disk cutter, (3) the cylindrical section is cut in two places $180^{\circ}$ apart and removed with a grapple, (4) the particulates are removed with a suction hose, and (5) the basket containing the SNF is lifted free of the debris. 


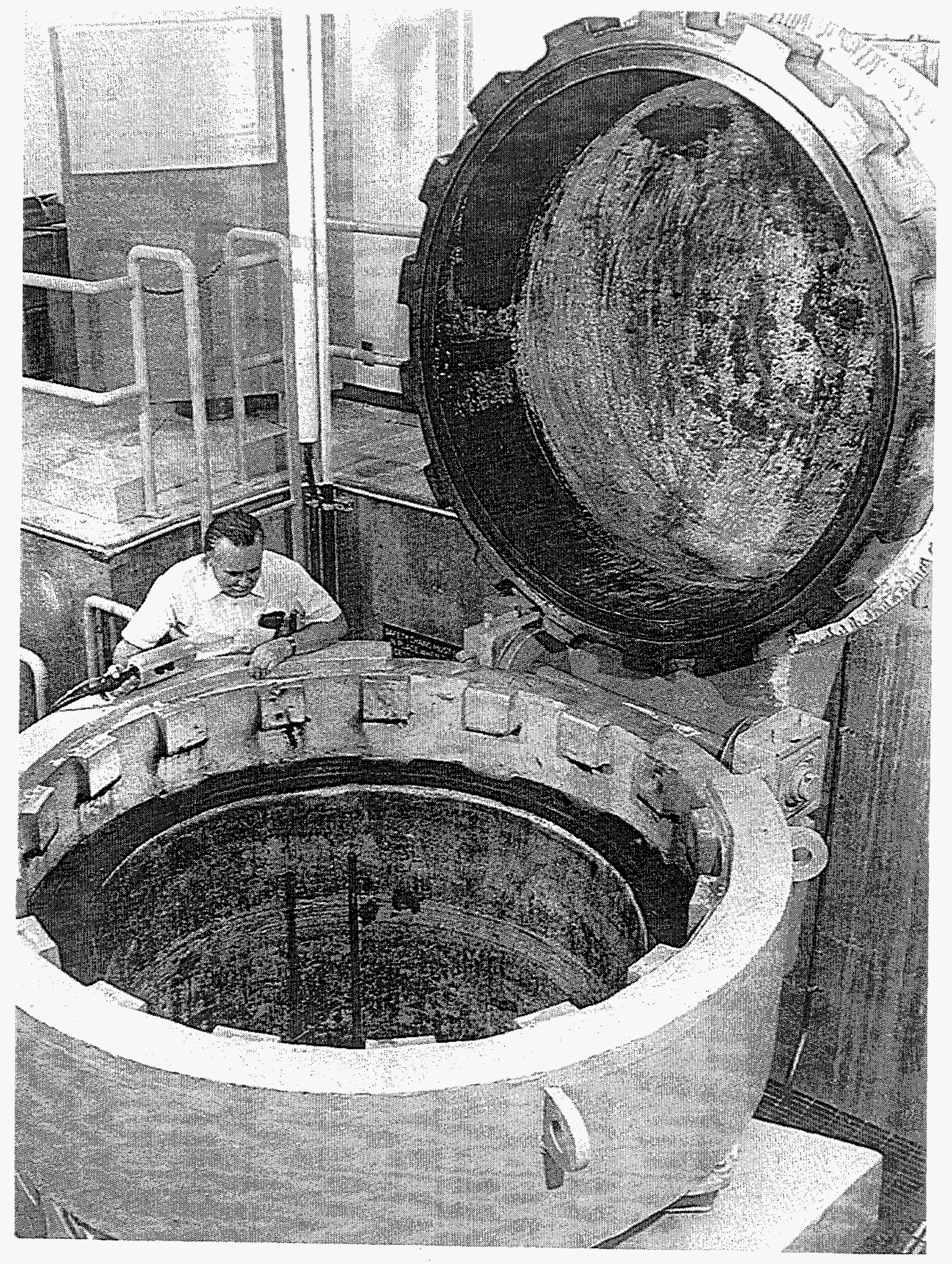

Figure 3.4. Whiteshell Hydrostatic Test Facility to test $W \mathrm{P}$ at $10 \mathrm{MPa}$ and $150^{\circ} \mathrm{C}$ (Courtesy of AECL). 


\subsection{THERMAL ANALYSIS OF THE WP}

Detailed thermal analyses of the WP with fill was completed (Baumgartner, Jhinger, and Tran 1994; Taralis 1981). Experimental measurements were made of the fill materials (Teper 1990). The results of the thermal analysis indicated small temperature drops across the WP. The analysis indicated also that most of the heat flowed through the metal basket structure, rather than through the particulate fill material, because of the high conductivity of the metal basket.

\subsection{PRODUCTION FACILITIES FOR FILLING WPS}

The AECL (AECL CANDU April 1992; Simmons and Baumgartner 1994) has developed a conceptual design of a repository with associated surface facilities-including cost estimates (Table 3.2). Final decisions on the design have not been made. The key surface facility is the Used-Fuel Packaging Plant (UFPP), which is sized to receive $4700 \mathrm{MTIHM} /$ year of CANDU SNF by rail or truck and to package that SNF into repository WPs. The peak throughput is about $15 \mathrm{WPs} / \mathrm{d}$. This throughput would be significantly larger than that of the proposed U.S. repository. The facility layout is shown in Fig. 3.5. There are two parallel processing lines within the UFPP plus storage for incoming SNF and outgoing WPs. The area associated with filling operations is the shake table. Fill and shake operations are done simultaneously.

SNF handling within the facility is somewhat different than that used for LWR SNF. CANDU fuel assemblies are small. Furthermore, in the design option considered, the facility must process 250,000 assemblies/year. To minimize handling, CANDU SNF assemblies, after discharge from the reactor, are placed into storage/transport modules. A single module holds 96 SNF assemblies. A module consists of 48 stainless-steel tubes welded to two tubesheets with 2 SNF assemblies stored in each tube. The SNF at the reactor is stored in these modules. It is planned to ship the SNF to the UFPP in these modules in transport containers containing one or more modules. At the UFPP, SNF will remain in the modules until it is loaded into the WP basket. (The UFPP facility equipment handles modules, not individual fuel assemblies.)

At the UFPP, the transport container is unloaded from the truck or train, inspected, cleaned, and moved under the module-handling cell. The top of the transport container is mated with the bottom of the hot cell. The transport container is opened and the SNF module is removed. The module may be dried and sent directly to the UFPP packaging cell, or the SNF module may be placed in the receiving-pool surge storage for processing at a later date. After the transport cask is unloaded, an empty module is placed inside the transport cask, the cask is sealed and returned to the power station. 
Table 3.2. One conceptual design of CANDU SNF used-fuel packaging plant

Facility requirements

SNF throughput, MTIHM/year

$$
4,730
$$

SNF throughput, assemblies/year

Receiving requirements

Transport modes

rail, truck

SNF modules/year

2,603

SNF assemblies/module

Full cask storage capacity, $d$

Empty cask storage capacity, $d$

Receiving pool capacity, months

Receiving pool capacity, modules

Packaging requirements

WP throughput, number/year

SNF assemblies, number/WP

Operations, $d$ /year

Operations, shifts/d

Facility size

Length, $m$

Width, $\mathrm{m}$ 


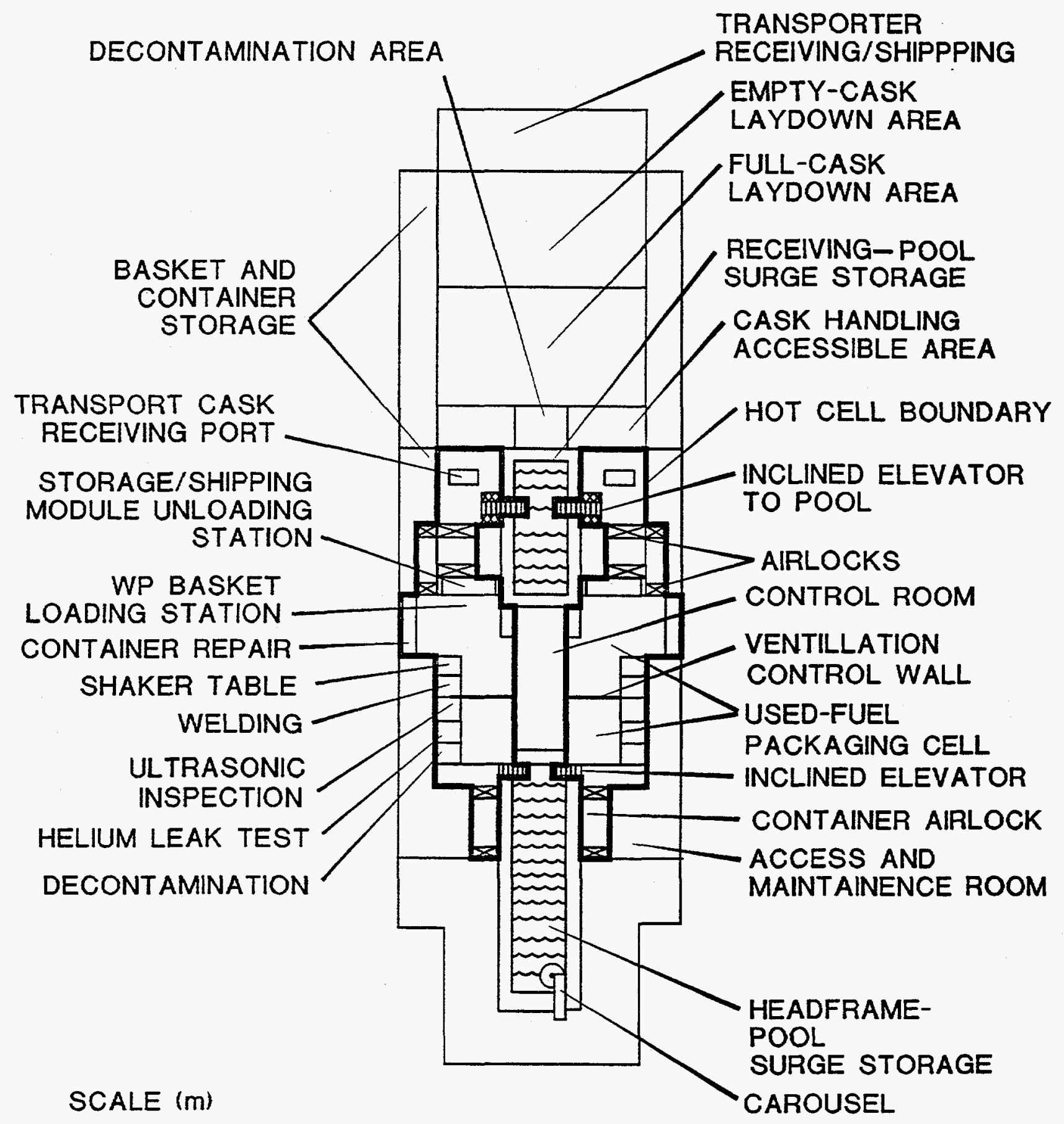

Fig. 3.5. Used-fuel packaging plant. 
In the used-fuel packaging cell, automated equipment simultaneously extracts CANDU fuel assemblies from the module, inspects the SNF, and loads the SNF directly into the WP basket, which is a bundle of schedule 10 steel pipes that are tack-welded together. Each steel pipe holds 4 SNF assemblies and the entire basket holds 72 assemblies. When the basket is full, it is placed within the outer titanium WP.

The full WP is placed on a shaker table (Fig. 3.6), and the glass-bead or sand particulate fill is added while the WP is vibrated. The table is supported on linear ball bearings on a static structure with an actuator attached near the center of gravity of the structure to provide horizontal vibratory motion during particle compaction. The particulate loading station hopper, metering device, and other components are located outside the hot cell to simplify operations and maintenance. A filler hose passes through the shielded wall to provide fill to the WP. About $566 \mathrm{~kg}$ of filler material is required per WP.

After the WP is filled with particulates, the lid is placed on top of the WP and welded into place. WP welds are ultrasonically inspected to meet the requirements of Sect. VIII of the ASME pressure vessel code. The WP then undergoes helium leak-testing to demonstrate that it is leak-tight.

If the WP does not pass all inspection tests, the WP is either repaired or cut apart to recover the SNF and the SNF is placed into a new WP. WPs could be overpacked; however, different size WPs would complicate underground operations. To minimize underground operations, the UFPP is designed to process any damaged WPs.

By examining Fig. 3.5, it is noted that the filling of the WP with particulates requires relatively small amounts of building floor space within the facility. This is a direct consequence of the relatively short time required to fill a WP with particulates and the many other operations required in the UFPP. 


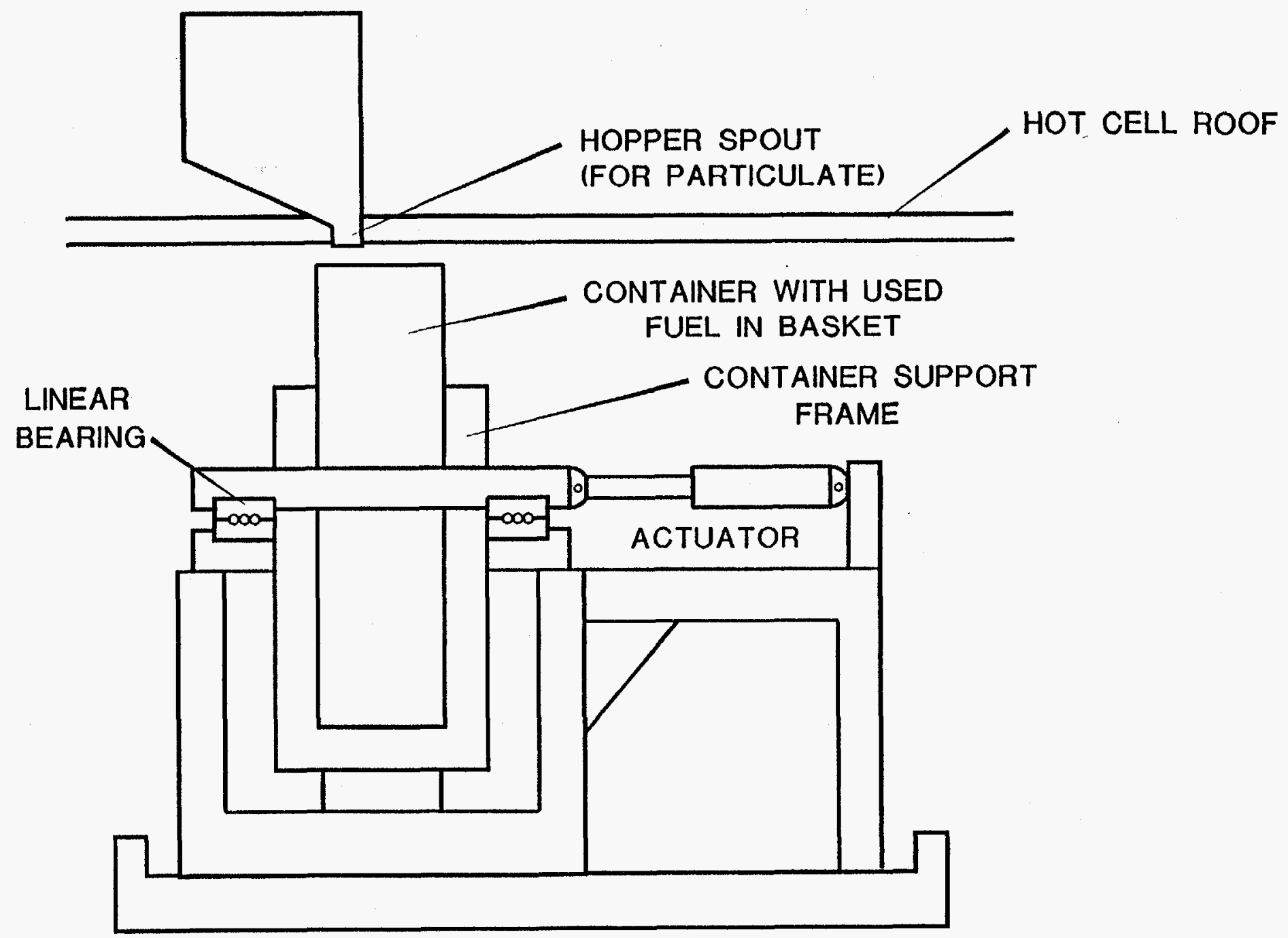

Fig. 3.6. Container filler and vibratory compactor. 



\section{CONCLUSIONS}

The large-scale, multiyear development of fill materials, WPs, inspection technologies, and facility designs for the Canadian repository system provide key data for the U.S. proposed use of DU fill in LWR SNF WPs. Specifically,

- the Canadian data provide reasonable confidence that DU fill operations are practicable,

- the Canadian data provide a basis to define a baseline DU fill concept that has an experimental basis in the selection of design parameters,

- the Canadian program provides a demonstrated forward path for development of DU as a WP fill material.

There are differences between a WP for CANDU SNF that uses glass or sand fill and a WP for LWR SNF that uses DU fill. These differences will necessitate some research and development for the use of DU fill in LWR SNF WPs. The Canadian data does, however, provide a solid foundation for such work. 


\section{REFERENCES}

AECL CANDU et al., April 1992. Used-Fuel Disposal Centre: A Reference Concept, TR-M-3, prepared for AECL Research, Whiteshell Laboratories, Pinawa, Manitoba, Canada.

Allan, C. J. and G. R. Simmons, September 1996. "Canada's Nuclear Fuel Waste Management Program: The Environmental Assessment of the Disposal Concept,"p. 39 in Geological Problems in Radioactive Waste Isolation, ed. P. A. Witherspoon, LBLN-38915, Ernest Orland Lawrence Berkeley National Laboratory, University of California, Berkeley, California.

Baumgartner, P., H. S. Jhinger, and T. Tran, 1994. The Equivalent Radial Thermal Conductivity of a UsedFuel Disposal Container, TR-620, COG-93-432, Chalk River Laboratories, Atomic Energy of Canada Limited, Chalk River, Ontario, Canada.

Cogar, J. A., 1996. WP Filler Material Testing Report, BBA000000-01717-2500-00008REV00, U.S. Department of Energy, Las Vegas, Nevada, 1996.

Crosthwaite, J. L., November, 1994. The Performance, Assessment, and Ranking of Container Design Options for the Canadian Nuclear Fuel Waste Management Program, TR-500, COG-93-410, Atomic Energy of Canada Limited Research Co., Pinawa, Manitoba, Canada.

Dyer, J. R. and M. D. Voegele, September 1996. "High-Level Radioactive Waste Management in the United States: Background and Status: 1996," p. 259 in Geological Problems in Radioactive Waste Isolation, ed. P. A. Witherspoon, LBLN-38915, Ernest Orland Lawrence Berkeley National Laboratory, University of California, Berkeley, California.

Forest, J. W., 1980. Impact and Fatigue Strength of Irradiated CANDU Fuel Bundles, 80-321-K, Ontario Hydro Research Division, Ontario Hydro Technologies, Toronto, Canada.

Forest, J. W., 1985. Irradiated Fuel Transportation Shock and Vibration Program-Phase II Summary, 85-190-K, Ontario Hydro Research Division, Ontario Hydro Technologies, Toronto, Canada.

Forsberg, C. W., January 1991. Representative Geological Repository Designs for Spent Fuel and HighLevel Waste, K/TP-393, Martin Marietta Energy Systems, Inc., Oak Ridge National Laboratory, Oak Ridge, Tennessee.

Forsberg, C. W. et al., 1995. DUSCOBS-A Depleted-Uranium Silicate Backfill For Transport, Storage, and Disposal of Spent Nuclear Fuel, ORNL/TM-13045, Martin Marietta Energy Systems, Oak Ridge National Laboratory, Oak Ridge, Tennessee.

Forsberg, C. W., December 1996. "Depleted Uranium Oxides and Silicates as Spent Nuclear Fuel WP Fill Materials," p. 615 in Proc. Materials Research Society 1996 Fall Meeting: Symposium II, Scientific Basis for Nuclear Waste Management XX, Materials Research Society, Pittsburgh, Pennsylvania.

Forsberg, C. W., September 1997. "Long-Term Criticality Control in Radioactive Waste Disposal Facilities Using Depleted Uranium," p. 99 in Proc. Criticality Safety Challenges in the Next Decade, Chelan, Washington, September 7-11, 1997, American Nuclear Society, La Grange Park, Illinois. 
Hart, R. S., 1994. "The CANDU 9," Proc. American Nuclear Society Advanced Reactor Safety Meeting Pittsburgh, Pennsylvania, April 18-20, 1994, American Nuclear Society, La Grange, Illinois.

Hausner, H. H., et al., 1967. Vibratory Compacting: Principles and Methods; Perspectives in Powder Metallurgy: Fundamentals, Methods, and Applications, Vol. 2, Plenum Press, New York.

Johnson, L. H. et al., April 1994. The Disposal of Canada's Nuclear Fuel Waste: Engineered Barriers Alternatives, AECL-10718, COG-93-8, Atomic Energy of Canada Limited Research, Whiteshell Laboratories, Pinawa, Manitoba, Canada.

Maak, P. Y. Y., 1985. Evaluation of Fusion Welds in a Prototype Thin-Wall Irradiated-Fuel Container, M84-175-K, Ontario Hydro Research Division, Ontario Hydro Technologies, Ontario, Canada.

Matthews, R. B. and M. L. Swanson, 1979. "Fabrication of Large (Th,U)O $\mathrm{O}_{2}$ Microspheres," Ceramic Bulletin, 58(2).

McCamis, R. H., 1992. Criticality Safety Calculations in Support of the Used-Fuel Disposal Vault, TR-537, COG-92-342, Chalk River Laboratories, Atomic Energy of Canada Limited, Chalk River, Ontario, Canada.

McGeary, R. K., 1961. “Mechanical Packing of Spherical Particles," J. Am. Ceramics Soc. 44(10), 513.

Mikasinovic, M. and B. Teper, 1981. "The Design and Development Program for the Packed-Particulate Supported Container," p. 188 in Proc. I0th Information Meeting of the Nuclear Fuel Waste Management Program, TR-166, Chalk River Laboratories, Atomic Energy of Canada Limited,

Chalk River, Ontario, Canada.

Mikasinovic, M. and R. Hoy, 1982. "Design of Packed Particulate Supported Containment for Irradiated Fuel Immobilization," p. 60 in Proc. Canadian Nuclear Society International Conference on Radioactive Waste Management, Winnipeg, MB, Canada, 1982.

Schutjens, P. M. T. M., 1991. "Experimental Compaction of Quartz Sand at Low Effective Stress and Temperature Conditions," J. Geological Society (London) 148, 527.

Shelson, K. N., 1983. Particulate Packings for Irradiated Fuel Disposal Containers, Report No. 83085, Ontario Hydro Design and Development Division, Ontario Hydro Technologies, Toronto, Canada.

Simmons, G. R. and P. Baumgartner, 1994. The Disposal of Canada's Nuclear Fuel Waste: Engineering for a Disposal Facility, AECL-10715, COG-93-5, Atomic Energy of Canada Limited.

Taralis, D., 1981. Determination of an Equivalent Thermal Conductivity of Sand-Packed Thin-Wall Container for Irradiated Fuel, 81-151-K, Ontario Hydro Research Division Report, Ontario Hydro Technologies, Toronto, Canada.

Teper, B., December 1980. Particulate Compaction Tests for a Particulate-Packed Thin-Wall Container for Irradiated-Fuel Disposal, TR-131, Atomic Energy of Canada Limited, Chalk River Laboratories, Ontario, Canada. 
Teper, B., 1981a. Preliminary Evaluation of Stress-Strain Distribution in Particulate-Packed Container, 81-316-K, Ontario Hydro Research Division, Ontario Hydro Technologies, Toronto, Canada.

Teper, B., 1981b. Proposal for Prototype Test Program of the Particulate-Packed, Thin-Wall Container, 81-333-K, Ontario Hydro Research Division, Ontario Hydro Technologies, Toronto, Canada .

Teper, B., 1982. "Preliminary Evaluation of the Design of Particulate-Packed, Thin-Wall Container for Disposal of Irradiated Fuel Bundles," p. 65 in Proc. Canadian Nuclear Society International Conference on Radioactive Waste Management, Winnipeg, Manitoba, Canada, September 12-15, 1982.

Teper, B., 1985. Test Program of the Prototype of the TWPP Container: Part 2-Post-Hydrostatic Tests, 85-313-K, Ontario Hydro Research Division, Ontario Hydro Technologies, Toronto, Canada.

Teper, B., 1986. "Feasibility Assessment of the Thin Walled Particulate-Packed Container," p. 285 in Proc. Waste Management '86, Symposium on Waste Management, Tucson, Arizona, 1986, Vol. 2., American Nuclear Society, La Grange Park, Illinois.

Teper, B., 1987a. Test Program of Granular Materials for the Thin-Walled Particulate-Packed Container, 87-154-K, Ontario Hydro Research Division, Ontario Hydro Technologies, Toronto, Canada.

Teper, B., 1987b. Test Program of the Prototype of the Thin-Wall Particulate-Packed (TWPP) Container: 1-Hydrostatic Tests, TR-369-1, Chalk River Laboratories, Atomic Energy of Canada Limited, Chalk River, Ontario, Canada (also Ontario Hydro Research Division Report 84-293-K).

Teper, B., 1988a. Test Program of the Prototype of the TWPP Container: Part 3-Detailed Stress Analysis and Comparison with Test Results, 87-296-K, Ontario Hydro Research Division, Ontario Hydro Technologies, Toronto, Canada.

Teper, B., 1988b. Feasibility Assessment of the Thin-Walled, Particulate-Packed Container, 87-274-K, Ontario Hydro Research Division, Ontario Hydro Technologies, Toronto, Canada.

Teper, B., 1990. Heat Transfer in Granular Materials, Report: B90-12-K, Ontario Hydro Research Division, Ontario Hydro Technologies, Toronto, Canada.

Teper, B., 1991. Drop Test Program for the Thin-Wall, Particulate-Packed Container, 91-25-K, Ontario Hydro Research Division, Ontario Hydro Technologies, Toronto, Canada.

Teper, B. and S. A. Reid, 1989. "Recent Developments in Design of Containers for Disposal of High Level Waste from CANDU Reactors," p. 623 in Proc. Waste Management '89, Tucson, Arizona, 1989, American Nuclear Society, La Grange Park, Illinois.

U. S. Department of Energy, December 1996. Integrated Data Base Report-1995: U.S. Spent Nuclear Fuel and Radioactive Waste Inventories, Projections, and Characteristics, DOE/RW-0006, Rev. 12, Washington, D.C.

U. S. Nuclear Waste Technical Review Board, 1977. Report to the U.S. Congress and the Secretary of Energy: January to December 1996, Washington, D.C. 
U.S. Nuclear Waste Technical Review Board, April 1996. Report to the U.S. Congress and the Secretary of Energy: 1995 Findings and Recommendations, Washington D.C.

Wasywich, K. M., 1993. Characteristics of Use CANDU Fuel Relevant to the Canadian Nuclear Waste Management Program, AECL-10463, COG-91-340. 
Appendix A:

DESCRIPTION OF THE USE OF DEPLETED URANIUM DIOXIDE FILL IN LWR SNF WPS 



\section{A.1 INTRODUCTION}

The use of depleted uranium (DU) dioxide $\left(\mathrm{UO}_{2}\right)$ as a repository waste-package (WP) fill material is being investigated (Forsberg 1996) for improvement of WP performance with packages containing lightwater reactor (LWR) spent nuclear fuel (SNF). A synthesis of existing laboratory data on uranium oxides, hot-cell tests on SNF, geological field data, and other data provide the technical basis for the concept. A description of the concept is provided herein. The mechanisms are described for (1) reduction of long-term radionuclide release rates from the WP, (2) minimization of the potential of long-term nuclear criticality in the repository, and (3) reduction of the radiation levels to the WP.

\section{A.2 CONCEPT: APPLICATION TO A REPOSITORY}

The repository WP is loaded with LWR SNF. The WP void space is then filled with DU UO particulates, which are sufficiently small $(<\mathrm{lmm})$ such as to fill coolant channels in the SNF assemblies and spaces between the fuel assemblies and the interior wall of the WP. A simplified schematic of a loading method is shown in Fig. A.1. Table A.1 identifies key characteristics of a representative WP using DU fill. The DU particulate enrichment levels are as low as $0.2 \mathrm{wt} \%{ }^{235} \mathrm{U}$. Thus, adding DU to the WP reduces the total fissile material concentration in the WP to below $1 \mathrm{wt} \%$ of the heavy metal. In the base case, the DU fill would be loaded at the repository. The technology is applicable to LWR SNF and potentially applicable to high-enriched-uranium SNF.

It is expected that the use of fill material will have little impact on the design of the external WP. The external WP walls can include added DU, if desired. The WP would probably be filled with the $\mathrm{DU} \mathrm{UO}_{2}$ fill at the repository, but the fill could also be added to transport and storage cask baskets when the basket is to be sent to the geological repository for disposal.

\section{A.3 REPOSITORY BENEFITS}

\section{A.3.1 Reduction of Radionuclide Release Rate from the Repository WP}

The expected repository failure mode is radionuclide migration to the open environment by (1) WP failure, (2) leaching of SNF by water, (3) dissolution of radionuclides and generation of colloids, and (4) transport of those radionuclides in dissolved or colloidal forms to the open environment. Three mechanisms reduce radionuclide release rates from WPs: (1) minimizing the water flow through the WP, (2) reducing the dissolution rate of radionuclides into groundwater, and (3) minimization of colloid transport by blocking flow paths. Delaying the release of radionuclides from the WP by these mechanisms provides the time for many of the radionuclides to decay to nonradioactive isotopes or less hazardous radionuclides. The use of DU fill uses all of these mechanisms to improve WP performance for geological repositories with oxidizing conditions, such as the proposed repository at Yucca Mountain. 


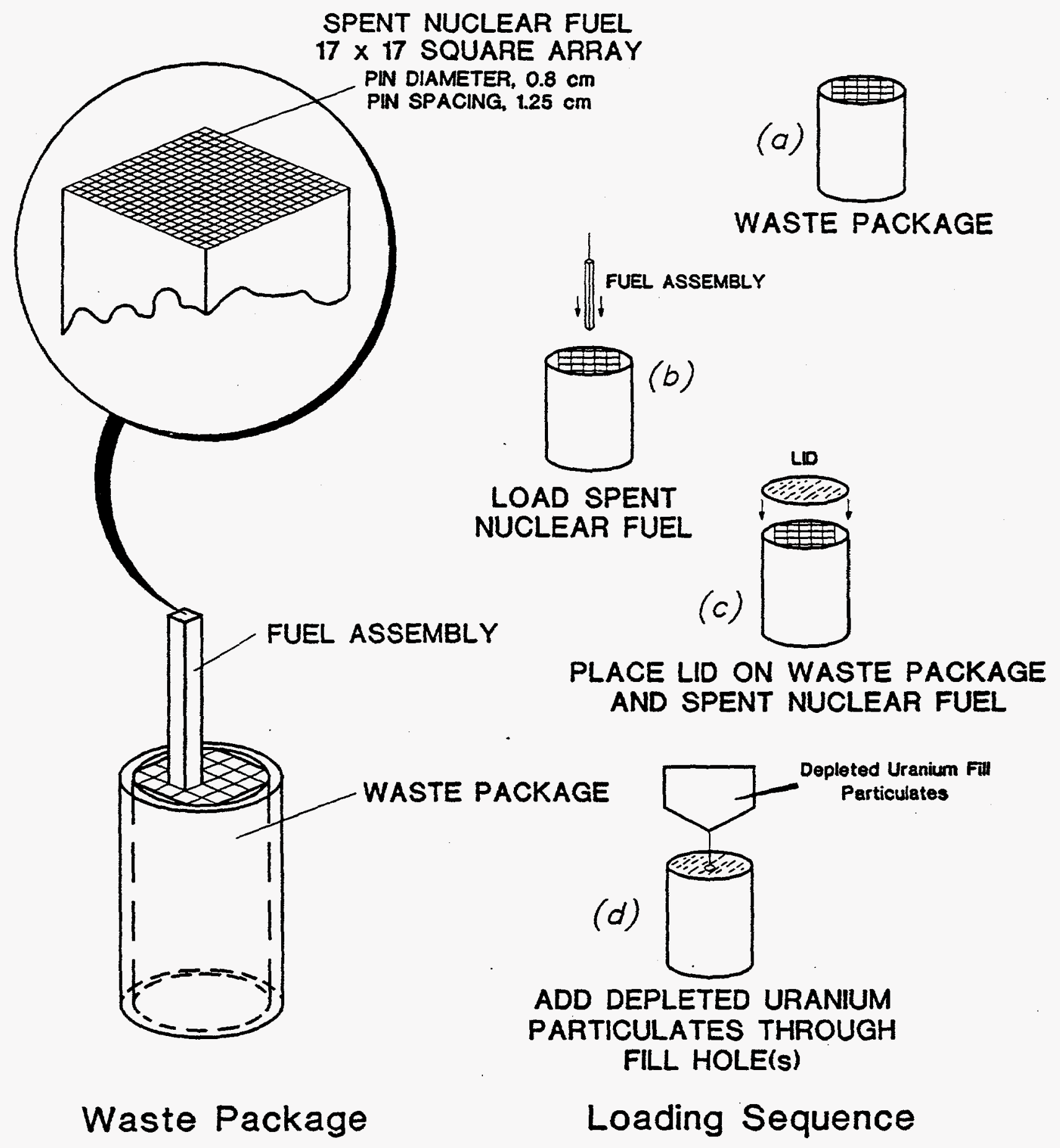

Fig. A.1. WP system and example loading sequence for DU particulates. 
Table A.1. DU dioxide WP fill characteristics ${ }^{\mathrm{a}}$

\begin{tabular}{|c|c|}
\hline Property & Value \\
\hline SNF, MTIHM & 9.96 \\
\hline Solid-bead density ${ }^{\mathrm{b}}, \mathrm{g} / \mathrm{cm}^{3}$ & 10.96 \\
\hline DU, wt \% of fill & 88 \\
\hline DU mass ${ }^{c}, t$ & 32.3 \\
\hline Particulate mass ${ }^{\mathrm{c}}, \mathfrak{t}$ & 36.7 \\
\hline Assay, wt $\%$ of $\mathrm{DU}^{235} \mathrm{U}$ & 0.2 \\
\hline Equivalent ${ }^{235} \mathrm{U}$ assay, wt \% of SNF & 1.6 \\
\hline Equivalent ${ }^{235} \mathrm{U}$ assay, wt \% of WP & 0.53 \\
\hline
\end{tabular}

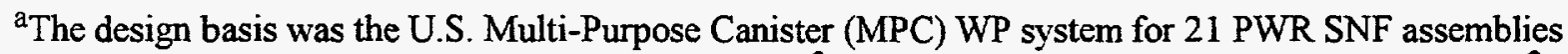
(DOE 1994). The MPC has an internal volume of $7.9 \mathrm{~m}^{3}$, the SNF baskets have a solid volume of $1.1 \mathrm{~m}^{3}$, and the 21 SNF assemblies have a solid volume of $1.6 \mathrm{~m}^{3}$. A total of $5.2 \mathrm{~m}^{3}$ of the $7.9 \mathrm{~m}^{3}$ of internal volume can be filled with beads.

${ }^{\mathrm{b}}$ The bead density can be controlled by the process parameters used in making the $\mathrm{UO}_{2}$. High densities are possible using standard fuel fabrication technologies. The preferred density will involve both economic and performance considerations.

'The fill fraction is 0.64 ; that is, $64 \%$ of the initial void space is filled with $\mathrm{UO}_{2}$ particulates and $36 \%$ of the initial void space remains void space between the particulates. Large-scale Canadian tests have measured volume fill fractions up to $\sim 73 \%$.

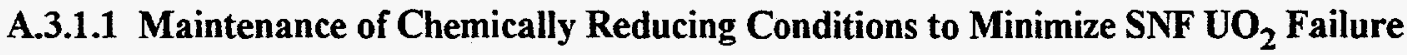

Most fission products and actinides within SNF are incorporated within $\mathrm{UO}_{2}$ crystals in SNF pellets. Upon WP failure and after entry of groundwater into the WP, these fission products and actinides can not escape the $\mathrm{UO}_{2}$ crystals until the $\mathrm{UO}_{2}$ dissolves or is transformed into another chemical species.

Maintaining chemically reducing conditions within the WP maintains the integrity of the SNF $\mathrm{UO}_{2}$ crystals by multiple mechanisms and, hence, reduces radionuclide releases. With the use of $\mathrm{UO}_{2}$ or other uranium compounds with uranium in the +4 valence state as fill materials, the DU fill ensures chemically reducing conditions within the WP for an extended time independent of external groundwater chemistry. After WP failure, any oxygen in the groundwater would first encounter the DU before it encounters the SNF. 
The DU in the +4 chemical state would be oxidized to the +6 chemical state through a series of oxidation steps, thus removing the oxygen from the groundwater and maintaining chemically reducing conditions in the WP.

The solubility of uranium in reducing groundwater is very low (Smellie, Karisson, and Grundfelt 1995)-about $1 \mathrm{ppb}$. This solubility is up to four orders of magnitude less than the solubility of uranium under oxidizing conditions. Radionuclide releases from SNF are extremely limited under chemically reducing conditions (Smellie, Karlsson, and Grundfelt 1995) because the $\mathrm{UO}_{2}$ does not dissolve and release the radionuclides incorporated within its crystalline structure. Chemically reducing conditions also minimize the solubility and transport of several other long-lived radionuclides (e.g., neptunium and technetium) and reduce the formation and transport of radionuclides as colloids.

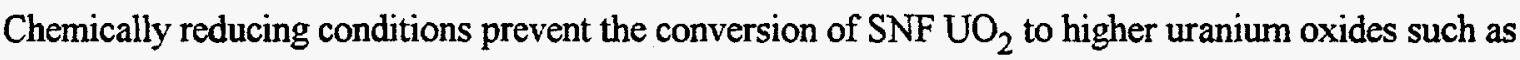
$\mathrm{U}_{3} \mathrm{O}_{8}$. When $\mathrm{UO}_{2}$ is oxidized, its crystal structure changes. In the process of converting from one crystal form to another, some radionuclides are released from the matrix. In particular, noble gases and some soluble radionuclides (if water is present) will be released to the air and water in the WP.

The DU fill also minimizes generation of oxidizing acids that degrade the WP and accelerate SNF dissolution. Water and air in radiation fields generate corrosive acids (e.g., nitric acid). WPs are dried and filled with inert gases before sealing to minimize this problem. After WP failure, DU fill reduces acid generation by two mechanisms. The high-density fill reduces internal WP radiation fields and the available WP air or water volume for acid generation is reduced by displacement with DU fill.

\section{A.3.1.2 Saturation of Groundwater with DU}

Surrounding the SNF with DU saturates any groundwater which may enter a degraded WP with uranium. This saturation slows the SNF dissolution process because DU-saturated groundwater can not dissolve additional SNF uranium.

\section{A.3.1.3 Protection from Variable Groundwater Chemistry}

The use of $\mathrm{DU}$, particularly $\mathrm{UO}_{2}$, provides a mechanism to counteract any unexpected changes in groundwater that may accelerate degradation of the SNF. Groundwater chemistry can change because of climatic changes and human activities (e.g., irrigation, groundwater pumping, liquid-waste injection, etc). The DU UO $\mathrm{O}_{2}$ acts as a sacrificial chemical to absorb changes in groundwater chemistry and delay their effects on the SNF $\mathrm{UO}_{2}$. 


\section{A.3.1.4 Support of WP Integrity and Secondary Barriers To Radionuclide Releases}

Fill material helps maintain other barriers to radionuclide migration. Ultimately, the WP will lose its structural strength. With a fill material, the basic geometry of the WP is maintained after loss of structural integrity of the WP. Without a fill material, the WP will (1) itself collapse, (2) collapse any secondary barriers to water flow, and (3) create a bed of rubble that is more permeable to groundwater flow. This benefit applies to any fill material, not just to DU.

\section{A.3.1.5 Minimization of the Groundwater Flow in WP}

After WP failure, DU fill lowers the hydraulic conductivity within the degraded WP and; thus, ensures low groundwater flow near the SNF. Water flow is the primary mechanism for the transport of radionuclides to the open environment. The release of many radionuclides is controlled by solubility limits. Other radionuclides may be transported by colloids. The slower the flow of groundwater, the slower the transport of radionuclides. The goal is to create a WP where water flow and radionuclide migration are by diffusion only because diffusion is a very slow process for transport of any radionuclide.

In oxidizing groundwater, the DU oxide fill will evolve to lower-density, higher-valence state, hydrated, uranium oxides (Finn, Hoh, Bates, and Wolf 1994; Murphy June 1992; Smith, Schettz, Anderson, and Smith 1982). Over much longer time periods, these compounds will evolve further into hydrated uranium silicates. The silica is provided by the groundwater. These changes have been observed in the laboratory and in uranium ore deposits (Pearcy, Prikryl, Murphy, and Leslie 1994; Murphy and Pearcy 1992). This reduction in density and accompanying volume expansion fills the void space and, thus, minimizes water flow. Figure A.2 shows this evolutionary sequence as it has been observed in natural uranium ore bodies with oxidizing groundwater (Murphy November 1995). Because of the high surface area of the particulates and because they are not protected by the SNF clad, they will expand and choke off groundwater flow to the SNF. Figure A.3 shows the conversion of $\mathrm{UO}_{2}$ to $\mathrm{U}_{3} \mathrm{O}_{8}$ that initially occurs. The desired expansion can be controlled by design.

\section{A.3.2 Reduction of the Potential for Repository Nuclear Criticality}

Both short-term and long-term nuclear criticality are to be avoided in a geological repository. A nuclear criticality event would generate added radioactivity and heat. The heat can accelerate degradation of WPs and movement of water that may transport radionuclides to the environment. The added radioactivity and heat also create uncertainties in the modeling of the long-term performance of the repository. These and other considerations have led to the licensing requirement that nuclear criticality be avoided in a geological repository. 
ORNL DWG 96A-326R

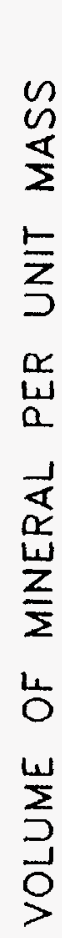

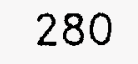

कू 200

दे है

宸

更

\begin{tabular}{l}
\hline \\
\hline \\
\hline \\
\hline
\end{tabular}

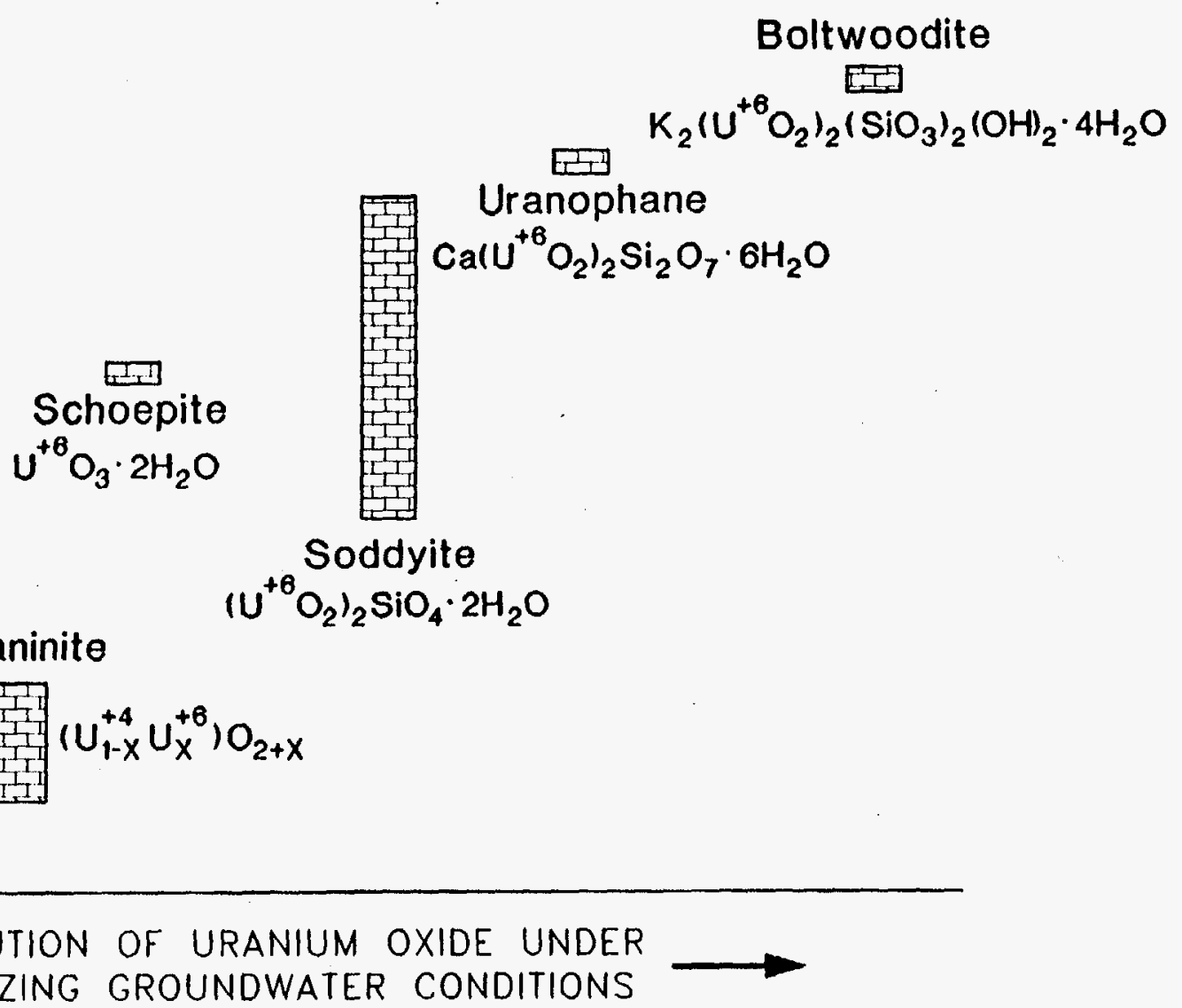

Fig. A.2. Specific volume of selected uranium minerals vs evolution over time in oxidizing groundwater. 
ORNL DWG 97C-219

\section{Initial Conditions}

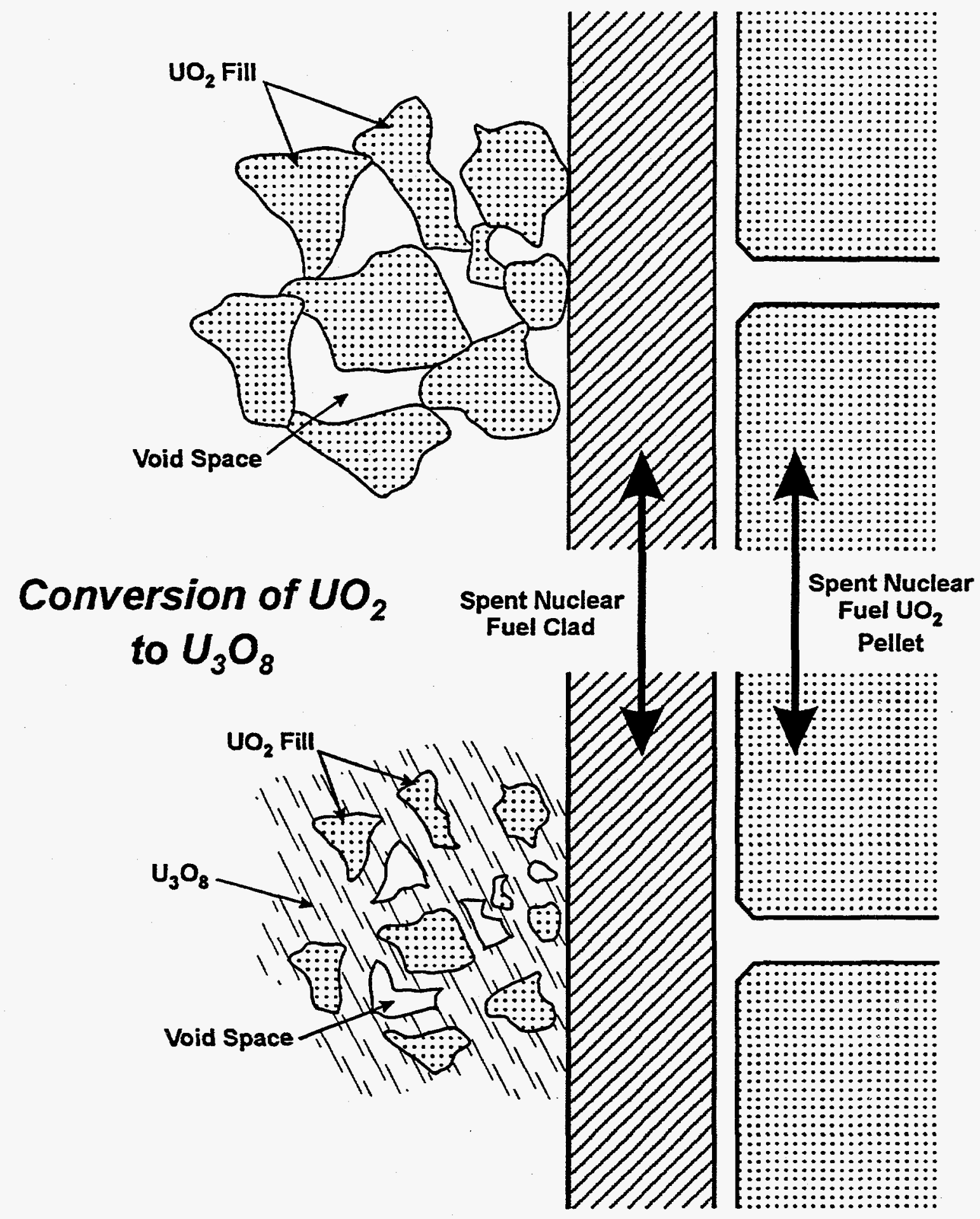

Fig. A.3. Conversion of $\mathrm{UO}_{2}$ to $\mathrm{U}_{3} \mathrm{O}_{8}$ with reduction in WP water and air permeability. 
The use of DU as a fill material reduces the potential for repository nuclear criticality events by lowering the fissile assay of a WP below $1 \mathrm{wt} \%{ }^{235} \mathrm{U}$. The average enrichment of SNF (all fissile isotopes) is $\sim 1.5 \mathrm{wt} \%$ (Ashline and Forsberg 1996). There is a wide distribution of fissile concentrations within the SNF inventory. It is generally accepted that a nuclear criticality event will not occur in geologic time at enrichments $<1$ wt \% ${ }^{235} \mathrm{U}$ equivalent (Naudet 1978; Cowan 1976; Forsberg 1997).

Because of possible uranium dissolution, groundwater transport, and redeposition (a mechanism that creates uranium ore bodies), it has been suggested that the potential for criticality events exists if the fissile concentration in the repository SNF is sufficiently high. Criticality during operations is prevented in a repository by (1) geometric spacing of fissile materials and (2) neutron absorbers. The degradation of the WP and SNF will ultimately change the geometry of the WP and, thus, complicate the use of geometry control for long-term criticality control. Neutron absorbers include ${ }^{238} \mathrm{U}$, boron, gadolinium, and other materials. Neutron absorbers (except ${ }^{238} \mathrm{U}$ ) leach from WPs and travel at rates different from the SNF uranium through the geologic media because of the different chemistries of the neutron absorbers in groundwater. The phenomena applies to both deep geological repositories and shallow disposal sites [Nuclear Regulatory Commission (NRC), June 1997].

The separation and concentration mechanisms for uranium in a repository are the same as those for uranium in the natural environment. In effect, the same phenomena that created natural reactors in the distant past may create the potential for nuclear criticality events in the future (International Atomic Energy Agency 1978). Uranium under oxidizing conditions is several orders of magnitude more soluble than uranium under chemically reducing conditions. This allows uranium to be oxidized to the +6 valence state by oxidizing groundwater, dissolve in the groundwater, be transported by the groundwater, and precipitate from groundwater when the local geological conditions create chemically reducing conditions. Potential chemical reducing agents are natural organics and many WP materials, such as iron. Figure A.4 shows one such scenario. The use of DU as a neutron absorber minimizes these concerns because DU has the same chemical properties as SNF uranium and, thus, does not separate from the SNF uranium. It minimizes potential criticality concerns inside, near, and far from the WP.

In LWR SNF, much of the fissile material is ${ }^{239} \mathrm{Pu}$. The foregoing analysis is based on the assumption that plutonium remains with the uranium until the major plutonium isotope $\left({ }^{239} \mathrm{Pu}\right)$ decays to ${ }^{235} \mathrm{U}$ and can be isotopically diluted by the DU. This isotopic dilution is ensured if the rate of plutonium decay to uranium is faster than the rate of dissolution and transport of uranium within the repository. Plutonium-239 has a halflife of 24,000 years (i.e., the decay rate is $3 \times 10^{-5} /$ year). Performance assessments indicate that plutonium migration is slow in most geological environments; thus, DU fill provides a basis for long-term criticality control of both ${ }^{239} \mathrm{Pu}$ and its decay product ${ }^{235} \mathrm{U}$. 


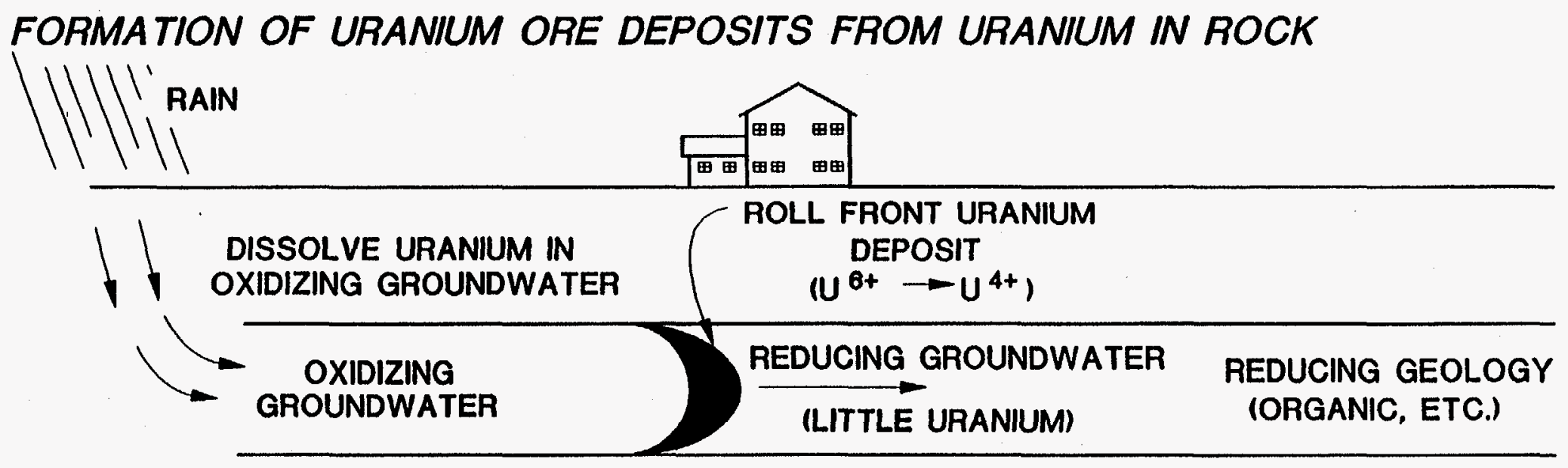

FORMATION OF URANIUM ORE DEPOSITS FROM URANIUM WASTES
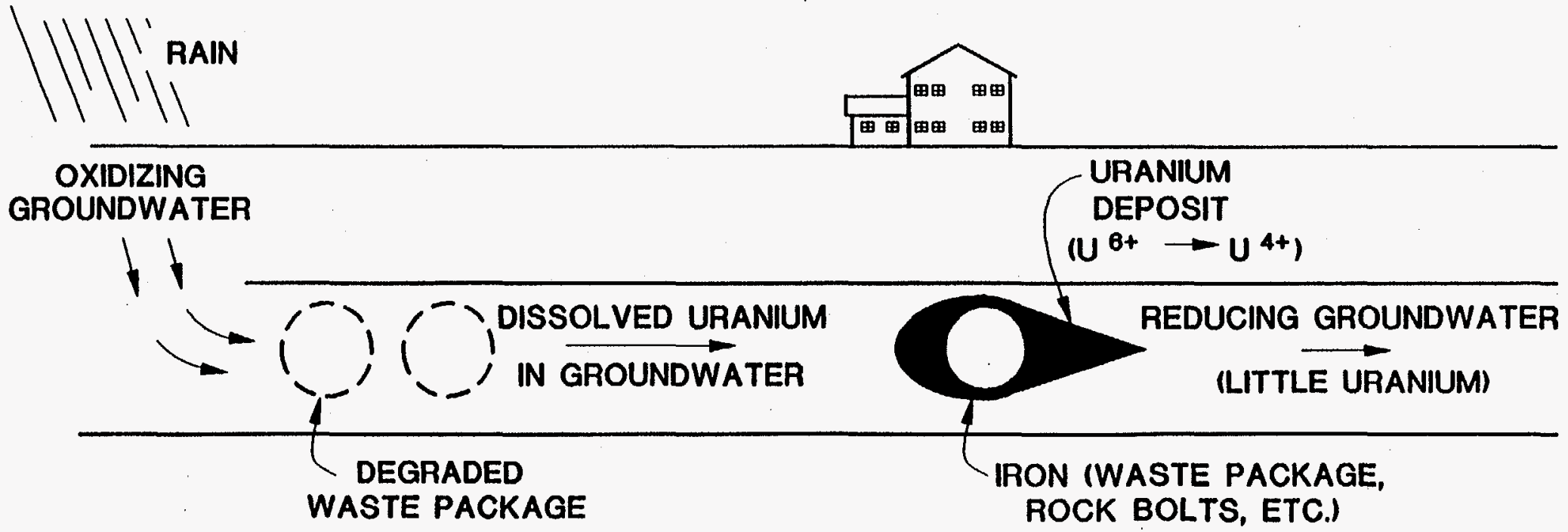

Fig. A.4. Natural and man-made formation of uranium ore bodies. 


\section{A-12}

\section{A.3.3 Enhanced Shielding}

WP shielding is required to reduce radiation interactions between the WP and the local geologic environment. This minimizes the complications in assessing long-term WP and repository performance. WP shielding may also be used to minimize the need for shielded equipment to place WPs in the repository. The use of a DU fill reduces radiation levels to the inside surface of the WP. This allows a reduction in shielding to be incorporated into the WP or lower radiation levels external to the WP. This shielding effect of the DU fill decreases the physical size of the WP because it is incorporated into the unused void spaces inside the WP.

\section{A.4 SCIENTIFIC BASIS OF DESIGN}

A focus of repository design is on the prediction of long-term performance over geologic time. Because the kinetic dissolution mechanisms of WP and SNF degradation may be temperature-dependent and influenced by radiolysis rates, results from accelerated laboratory testing of materials are difficult to extrapolate to repository time-frames. Knowledge of uranium ore body behavior provides useful insight. In ore deposits, $\mathrm{UO}_{2}$ evolves into hydrated uranium silicate minerals in conditions similar to those at Yucca Mountain (Murphy November 1995). In these ore deposits, uranium at the outer edges of the deposits protects internal uranium against dissolution. The use of DU fill material in SNF WP mimics this natural phenomenon. Geological data on the performance of $\mathrm{UO}_{2}$ over millions of years can be used, when combined with laboratory data, to provide estimates of WP performance and support licensing.

Many natural uranium deposits contain sufficient ${ }^{235} \mathrm{U}$ mass to become nuclear reactors. However, this does not happen because ${ }^{235} \mathrm{U}$ in natural uranium is isotopically diluted with ${ }^{238} \mathrm{U}$. The DU fill strategy applies this same strategy for criticality control to WPs.

\section{A.5 MANAGEMENT OF DU}

There is sufficient DU to implement the concept. For LWR fuel production, natural uranium with a ${ }^{235} \mathrm{U}$ content of $0.71 \%$ is separated into an enriched-uranium fraction with the by-product production of 4 to 6 tons of DU per ton of enriched uranium. Currently, there are only limited uses for this material. Worldwide there is in excess of $1,000,000 \mathrm{t}$ of DU in storage. In the United States, about $400,000 \mathrm{t}$ of DU is in storage with various ${ }^{235} \mathrm{U}$ assays. About a third of the inventory has assay levels below $0.21 \mathrm{wt} \%{ }^{235} \mathrm{U}$.

If this material is declared a waste, existing regulatory requirements indicate that some type of geological disposal will be required (NRC January 1994; Hickey September 22, 1992). Performance assessments 
(Martin Marietta Energy Systems, 1994) indicate that large quantities of uranium are probably not acceptable for shallow land disposal. The uranium must be converted to a stable form such as an oxide for disposal. Use of DU within SNF WPs eliminates the separate, not insignificant, cost of disposal of this material. The use of DU as a beneficial material to improve WP performance reduces legal and institutional constraints in the management of DU.

\section{A.6 CONCLUSIONS}

DU fill inside the WP creates the potential for significant improvements in WP performance based on uranium geochemistry, reduces the potential for nuclear criticality in a repository, and provides a beneficial use for DU.

\section{A.7 REFERENCES}

Ashline, R. C. and C. W. Forsberg, April 1996. "U.S. Light-Water Reactor Spent Fuel Inventory-Fissile Distribution," Proc. 1996 International High-Level Radioactive Waste Management Conference, Las Vegas, Nevada, April 29-May 3, 1996, American Nuclear Society, La Grange Park, Illinois.

Cowan, G. A., July 1976. “A Natural Fission Reactor," Sci. Am. 235, 36.

Finn, P. A., J. C. Hoh, J. K. Bates, and S. F. Wolf, 1994. "Behavior of Spent Fuel Under Unsaturated Conditions," pp. 421 in Proc. Topical Meeting: DOE Spent Nuclear Fuel-Challenges and Initiatives, Salt Lake City, Utah, December 13-16, 1994, American Nuclear Society, La Grange Park, Illinois.

Forsberg, C. W., December 1996. "Depleted Uranium Oxides and Silicates As Spent Nuclear Fuel WP Fill Materials," Proc. Materials Research Society 1996 Fall Meeting: Symposium II, Scientific Basis for Nuclear Waste Management $X X$, Vol. 465 Materials Research Society, Pittsburgh, Pennsylvania.

Forsberg, C. W., 1997. "Long-Term Criticality Control in Radioactive Waste Disposal Facilities Using Depleted Uranium," Proc. Criticality Safety Challenges in the Next Decade, Chelan, Washington, September 7-11, 1997, American Nuclear Society, La Grange Park, Illinois.

Hickey, J. W. N., September 22, 1992. Letter from J. Hickey, Chief Fuel Cycle Safety Branch, U.S. Nuclear Regulatory Commission to Louisiana Energy Services, L. P., Docket No. 70-3070, U.S. Nuclear Regulatory Commission, Washington, D.C.

International Atomic Energy Agency, 1978. Natural Fission Reactors, Proc. Meeting of the Technical Committee on Natural Fission Reactors, Paris France, December 19-21, 1977, Vienna, Austria.

Martin Marietta Energy Systems, Inc.; EG\&G Idaho, Inc.; and Westinghouse Savannah River Co., 1994. Radiological Performance Assessment for the E-Area Vaults Disposal Facility, WSRC-RP-94-218 (Oak Ridge National Laboratory, Grand Junction, Colorado). 
Murphy, W. M., June 1992. "Natural Analog Studies for Geological Disposal of Nuclear Waste," Technology Today, Southwest Research Institute, San Antonio, Texas.

Murphy, W. M., November 1995. "Natural Analogs for Yucca Mountain," Radwaste Mag., 2(6), 44.

Murphy, W. M. and E. C. Pearcy, 1992. "Source-Term Constraints for the Proposed Repository At Yucca Mountain, Nevada, Derived From the Natural Analog at Pena Blanca, Mexico," pp. 521-527 in Proc. Material Research Society, 257, Pittsburgh, Pennsylvania.

Naudet, S. R., 1978. “Etude Parametrique De La Criticite Des Reacteurs Naturels," pp. 589-589 in Natural Fission Reactors, Proc. Meeting of the Technical Committee on Natural Fission Reactors, Paris, France, December 19-21, 1977, IAEA-TC-119/22, International Atomic Energy Agency, Vienna, Austria.

Pearcy, E. C., J. D. Prikryl, W. M. Murphy, and B. W. Leslie, 1994. Applied Geochemistry, 9, 713-732 (1994).

Smellie, J. A. T., F. Karlsson, and B. Gundfelt, 1995. pp. 363-385 in Proc. GEOVAL '94: Validation Through Model Testing, Nuclear Energy Agency, Organization for Economic Co-operation and Development, Paris, France.

Smith, D. K., B. E. Schettz, C. A. F. Anderson, and K. L. Smith, 1982. "Phase Relations in the UraniumOxygen-Water System and Its Significance on the Stability of Nuclear Waste Forms," Uranium, 1, 79.

U.S. Department of Energy, Office of Civilian Radioactive Waste Management, 1994. Multi-Purpose Canister System Evaluation: A Systems Engineering Approach, U.S. Department of Energy, Washington, D.C.

U.S. Nuclear Regulatory Commission, January 1994. Safety Evaluation Report for the Claiborne Enrichment Center, Homer, Louisiana, Docket No. 70-3070, NUREG-1491, Washington, D.C.

U.S. Nuclear Regulatory Commission, June 1997. The Potential for Criticality Following Disposal of Uranium at Low-Level Waste Facilities, NUREG/CR-6505, Washington, D.C. 
Appendix B:

PUBLICATIONS ON THE USE OF DU FILL IN SNF WPS 


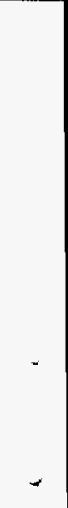


Forsberg, C. W., et al., 1995. DUSCOBS-A Depleted-Uranium Silicate Backfill For Transport, Storage, and Disposal of Spent Nuclear Fuel, ORNL/TM-13045, Lockheed Martin Energy Systems, Oak Ridge National Laboratory, Oak Ridge, Tennessee.

Forsberg, C. W. et al, 1996. "Depleted-Uranium-Silicate Backfill of Spent-Fuel Waste Packages for Repository Containment and Criticality Control," p. 366 in High Level Radioactive Waste Management 1996: Proc. Seventh Annual International Conference, Las Vegas, Nevada, April 29-May 3, 1996, American Nuclear Society, La Grange Park, Illinois.

Pope, R. B. 1996, "Benefits/Impacts of Utilizing Depleted Uranium Silicate Glass As Backfill For Spent Fuel Waste Packages," p. 369 in High Level Radioactive Waste Management 1996: Proc. Seventh Annual International Conference, Las Vegas, Nevada, April 29-May 3, 1996, American Nuclear Society, La Grange Park, Illinois.

Pope, R. B. et al., 1996. "Potential Benefits and Impacts on the CRWMS Transportation System of Filling Spent Fuel Shipping Casks With Depleted Uranium Silicate Glass," Spectrum '96: Proc.

Seattle, Washington, August 18-23, 1997, American Nuclear Society, La Grange Park, Illinois.

Forsberg, C. W., December 1997. "Depleted Uranium Oxides and Silicates As Spent Nuclear Fuel WP Fill Materials," p. 615 in Proc. Materials Research Society 1996 Fall Meeting: Symposium II, Scientific Basis for Nuclear Waste Management XX, Materials Research Society, Pittsburgh, Pennsylvania.

Forsberg, C. W., July 15, 1997. "Depleted Uranium Oxides As Spent Nuclear Fuel Waste Package Fill Material," U.S. Department of Energy Depleted Uranium Workshop, Las Vegas, Nevada, U.S. Department of Energy.

Forsberg, C. W., September 1997. "Long-Term Criticality Control in Radioactive Waste Disposal Facilities Using Depleted Uranium," p. 99 in Proc. Topical Meeting on Criticality Safety Challenges in the Next Decade, Chelan, Washington, September 7-11, 1997, American Nuclear Society, La Grange Park, Illinois.

Forsberg, C. W., (in preparation). Description of the Canadian Particulate-Fill Waste-Package (WP) System for Spent-Nuclear Fuel (SNF) and its Applicability to Light-Water Reactor SNF WPS with Depleted Uranium-Dioxide Fill, ORNL/TM-13502, Lockheed Martin Energy Research, Oak Ridge National Laboratory, Oak Ridge, Tennessee.

Forsberg, C. W., (in preparation). "In-Repository Depleted-Uranium Isotopic Mixing with LWR SNF for Long-Term Criticality Control," Proc. 1998 International High-Level Radioactive Waste Management Conference, Las Vegas, Nevada, May 11-14, 1998, American Nuclear Society, La Grange Park, Illinois.

Forsberg, C. W., (in preparation). "Fill Materials for Inside Spent Nuclear Fuel Waste Packages," Proc. 1998 International High-Level Radioactive Waste Management Conference, Las Vegas, Nevada, May 11-14, 1998, American Nuclear Society, La Grange Park, Illinois. 


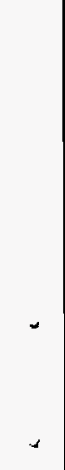




\section{INTERNAL DISTRIBUTION}

1. J. M. Begovich

2. G. D. Conner

3. A. G. Croff

4. N. H. Cutshall

5. L. R. Dole

6. K. R. Elam

7-11. C. W. Forsberg

12. M. J. Haire

13. C. M. Hopper

14. A. S. Icenhour

15. S. B. Ludwig
16. L. E. McNeese

17-21. G. E. Michaels

22. C. V. Parks

23. R. B. Pope

24. R. T. Primm, III

25. L. B. Shappert

26. K. D. Snyder

27. R. M. Westfall

28. Central Research Library

29. Laboratory Records-RC

30. Document Reference Section

\section{EXTERNAL DISTRIBUTION}

31. T. M. Ahn, U.S. Nuclear Regulatory Commission, MS T7-C6, Washington, D.C. 20555-0001.

32. D. H. Alexander, U.S. Department of Energy, MS S7-51, P.O. Box 550, Richland, Washington 99352.

33. J. Arendt, 109 Caldwell Dr., Oak Ridge, Tennessee 37830.

34. H. A. Benton, TRW Environmental Systems, Inc., MS 423-624, 1180 Town Center Dr., Las Vegas, Nevada 89134.

35. R. Bernero, 201 Summit Hall Dr., Gaithersburg, Maryland 20877.

36. R. F. Beyer, Westinghouse Electric Company, Bettis Atomic Power Laboratory, P.O. Box 79, West Mifflin, Pennsylvania 15122.

37. J. Blink, TRW Environmental Systems, Inc., MS 423-624, 1180 Town Center Dr., Las Vegas, Nevada 89134.

38. Charles E. Bradley, Jr., Program Manager, Office of Facilities, U.S. Department of Energy, Office of Nuclear Energy, Science, and Technology, 19901 Germantown Rd., Germantown, Maryland 20874.

39. Colette E. Brown, U.S. Department of Energy, Office of Nuclear Energy, Science, and Technology, NE-40, 19901 Germantown Rd., Germantown, Maryland 20874. 
40. R. J. Budnitz, Future Resources Associates, Inc., Suite 402, 2039 Shattuck Ave., Berkeley, California 94704.

41. Robert D. Busch, Nuclear Engineering Laboratory, Department of Chemical and Nuclear Engineering, 251 Farris Engineering Center, Albuquerque, New Mexico 87131-1341.

42. Donald E. Carlson, U.S. Nuclear Regulatory Commission, MS 06-G22, 11545 Rockville Pike, Rockville, Maryland 20852.

43. B. Clark, Lawrence Livermore National Laboratory, MS L-369, P.O. Box 808, Livermore, California 94550.

44. V. A. Colten-Bradley, U.S. Nuclear Regulatory Commission, MS T-7F3, 11545 Rockville Pike, Rockville, Maryland 20852.

45. T. Cotton, TRW Environmental Systems, Inc., Suite 800, 2650 Park Tower Dr., Vienna, Virginia 22180.

46. C. R. Cooley, U.S. Department of Energy, Office of Science and Technology, Environmental Management, 19901 Germantown Rd., Germantown, Maryland 20874-1290.

47. J. Les Crosthwaite, AECL Research, Whiteshell Laboratories, Pinawa, Manitoba, Canada, R0E 1LO.

48. Berta de la Cruz, CIEMAT, Ave. Computense 22, 28040 Madrid, Spain.

49. K. R. Czerwinski, Massachusetts Institute of Technology, Department of Nuclear Engineering, Rm. 24-210, 77 Massachusetts Ave., Cambridge, Massachusetts 02139.

50. Carl A. Detrick, Westinghouse Electric Company, Bettis Atomic Power Laboratory, P.O. Box 79, West Mifflin, Pennsylvania 15122.

51. M. Driscoll, Massachusetts Institute of Technology, Department of Nuclear Engineering, Bldg. 24-102, 77 Massachusetts Ave., Cambridge, Massachusetts 02139.

52. T. W. Doering, Framatome Cogema Fuels, 1180 Town Center Dr., Las Vegas, Nevada 89134.

53. R. E. Einziger, Battelle Pacific Northwest Laboratory, MS K2-45, P.O. Box 999, Richland, Washington 99352.

54. J. Garrick, PLG Inc., Suite 400, 4590 MacArthur, Newport Beach, California 92660.

55. E. Greenspan, University of California, Berkeley, Department of Nuclear Engineering, Berkeley, California 94720. 
56. Peter Gottleib, TRW Environmental Systems, Inc., MS 423-624, 1180 Town Center Dr., Las Vegas, Nevada 89134.

57. B. Halsey, Lawrence Livermore National Laboratory, MS L-369, P.O. Box 808, Livermore, California 94550.

58. S. Hanauer, U.S. Department of Energy, Office of Civilian Radioactive Waste Management, 1000 Independence Ave., S.E., Washington, D.C. 20585.

59. R. Henry, Idaho National Engineering Laboratory, P.O. Box 1625, Idaho Falls, Idaho 83415.

60. J. W. N. Hinkey, U.S. Nuclear Regulatory Commission, Division of Fuel Cycle Safety and Safeguards, MS T-8A33, Washington, D.C. 20555.

61. L. H. Johnson, Manager, Fuel Waste Technology Branch, AECL Research Whiteshell Laboratories, Pinawa, Manitoba, Canada, R0E IL0.

62. W. E. Kastenberg, University of California, Berkeley, Department of Nuclear Engineering, Berkeley, California 94720-1730.

63. J. H. Kessler, Electric Power Research Institute, Nuclear Power Group, 3412 Hillview Ave., Palo Alto, California 94304.

64. W. H. Lake, U.S. Department of Energy, Office of Civilian Radioactive Waste Management, DOE/RW-46, 1000 Independence Ave., S.E., Washington, D.C. 20585

65. J. D. Lee, Lawrence Livermore National Laboratory, MS L-634, 7000 East Ave., Livermore, California 94550.

66. C. McCombie, National Cooperative for the Disposal of Radioactive Waste, Hardstrasse 73, Wettingen, Switzerland.

67. M. A. McKinnon, Battelle Pacific Northwest Laboratory, MS K-8-34, P.O. Box 999, Richland, Washington 99352.

68. B. McLeod, JAI Corp., Suite 200, 4103 Chain Bridge Rd., Fairfax, Virginia 22030.

69. W. M. Murphy, Southwest Research Institute, Center for Nuclear Waste Regulatory Analysis, P.O. Drawer 28510, San Antonio, Texas 78228.

70. D. G. Olander, University of California, Berkeley, Department of Nuclear Engineering, Berkeley, California 94720-1730.

71. Virginia Oversby, Swedish Nuclear Fuel Cycle and Waste Management Company, Svensk Karnbranslehantering AB, S-102 40, P.O. Box 5864 , Stockholm, Sweden. 